\title{
Levels of technological adoption in pineapple production units in Loma Bonita, Oaxaca, Mexico
}

\author{
César Julio Martínez Castro ${ }^{{ }^{*}}$ \\ Maricela Ríos Castillo² \\ Maricela Castillo Leal ${ }^{3}$
}

\begin{abstract}
Currently, different technologies have been incorporated into pineapple crops in the municipality of Loma Bonita, Oaxaca. However, not all growers have done so in the same proportion, establishing technological differences between their production units. The main objective of this paper is to classify pineapple production units according to the levels of technological adoption they have in Loma Bonita. A total of 68 surveys were applied. The production units were classified using statistics such as interval, range and minimum and maximum limits. The descriptive analysis included statistics of central tendency and dispersion. Four levels of technology adoption were identified: very low, low, medium and high. $55.9 \%$ of the growers have a low level of technology adoption. The average age was 48 years, $32.4 \%$ expressed having more than 15 years of experience. There is a low incorporation of technologies and services such as shade mesh, mulching, pressurized irrigation systems, sowing the MD2 variety, soil analysis, water and technical advice. It is concluded that few growers with very low and low levels of technological adoption have or have been able to incorporate expensive technologies such as tractors, implements, irrigation systems, mulching and shade mesh.
\end{abstract}

Keywords: Socioeconomic features, technological features, pineapple growers.

\section{Niveles de adopción tecnológica en unidades de producción de piña en Loma Bonita, Oaxaca, México}

\section{Resumen}

Actualmente diversas tecnologías se han incorporado al cultivo de piña en el municipio de Loma Bonita, Oaxaca. Sin embargo, no todos los productores lo han hecho en la misma proporción: marcando diferencias tecnológicas entre sus unidades de producción. Esta investigación tuvo como objetivo principal clasificar las unidades de producción de piña de acuerdo con el nivel tecnológico con el que cuentan en Loma Bonita, Oaxaca. Se aplicaron 68 encuestas. Las unidades de producción se clasificaron empleando estadísticos como intervalo, rango y límites mínimos y máximos. El análisis descriptivo incluyó estadísticos de tendencia central y dispersión. Se identificaron cuatro niveles de adopción tecnológica: muy bajo, bajo, medio y alto. El 55.9 \% de los productores cuentan con bajo nivel de adopción tecnológica. La edad promedio fue de 48 años, 32.4 \% expresó contar con más de 15 años de experiencia. Se aprecia una baja incorporación de tecnologías y servicios como malla sombra, acolchado, sistemas de riego presurizado, siembra de la variedad MD2, análisis de suelo, agua y asesoría técnica. Se concluye que pocos productores de los niveles de adopción tecnológica muy bajo y bajo, cuentan o han podido incorporar tecnologías costosas como tractor, implementos, sistemas de riego, acolchado y malla sombra.

Palabras clave: Riego, organización social, infraestructura hidráulica.

'Universidad del Papaloapan, Campus Loma Bonita. Ingeniería Agrícola Tropical. Av. Ferrocarril s/n, col. Cd. Universitaria. Loma Bonita, Oaxaca. C.P. 68400.

Instituto Tecnológico de Nuevo León. Departamento de Ciencias Económico-Administrativas. Av. Eloy Cavazos núm. 2001. col. Tolteca Guadalupe, Nuevo León. C.P. 67170.

${ }_{3}^{3}$ Instituto Tecnológico de Oaxaca. ave. Ing. Víctor Bravo Ahujanúm.125, esq. Calzada Tecnológico, Oaxaca de Juárez, Oaxaca. C.P. 68030

${ }^{*}$ Corresponding author: c_julios4@hotmail.com. Tel. 01-281-8729230, ext. 221 


\section{Introduction}

According to statistics, Mexico is among the top ten nations in terms of volume of pineapple production (FAOSTAT, 2018; SAGARPA, 2016). Nationwide, the state of Oaxaca is the second largest grower of this fruit with a contribution that exceeds 130000 tons and represents $13.8 \%$ of the more than 945000 reported for 2017. In this entity, the municipality of Loma Bonita contributes with $73.2 \%$ of the state production (SIAP, 2018). Pineapple was introduced in this municipality during the first decade of the 20th century, where due to the agro-climatic conditions, characteristic of tropical regions; it adapted perfectly and began to be cultivated in greater proportion, to such an extent that by the decade of the twenties the first exports to the United States of America were made (Muñoz, 2001). So was the growth of the crop and exports that in a few years Loma Bonita achieved an international reputation earning the name of the world capital of pineapple (Traffano, 2012), name that has lost over time.

Although, at present time, the pineapple crop in Loma Bonita has diminished in importance compared to similar crops in the state of Veracruz, this crop continues to be the main agricultural activity in this municipality, which translates into economic and social benefits by representing a source of income for growers and the heads of household, generation of permanent and temporary jobs throughout the production process, which can last up to 18 months, the economic spillover generated during this process powering other economic activities related to the supply of inputs, machinery, equipment, tools and agricultural services, in addition to the processes of industrialization and commercialization (OEIDRUS Oaxaca, 2009; Rebolledo, Uriza, del Ángel, Rebolledo, \& Zetina,2011; Hernández \& Barrón, 2013).

Despite the above mentioned, in Loma Bonita, the technological differences between the pineapple production units are notorious, which would support what some authors have pointed out about the existence in the same region, municipality or locality, specially multiple ways of carrying out agriculture (Dufumier, 1990; Escobar \& Berdegué, 1990; Duch, 1998). According to various assertions, this is due to the fact that in a specific geographical space growers can converge with or without the interest of using

\section{Introducción}

De acuerdo con las estadísticas, México figura entre las primeras diez naciones en cuanto a volumen de producción de piña (FAOSTAT, 2018; SAGARPA, 2016). A nivel nacional, el estado de Oaxaca es el segundo productor de esta fruta con una aportación que rebasa las 130 mil toneladas y representa el $13.8 \%$ de las más de 945 mil reportadas para el año 2017. En esta entidad, el municipio de Loma Bonita participa con el $73.2 \%$ de la producción estatal (SIAP, 2018). La piña fue introducida en este municipio durante la primera década del siglo XX, donde por las condiciones agroclimáticas características de las regiones tropicales se adaptó perfectamente y se comenzó a cultivar en mayor proporción, a tal grado que para la década de los años veinte se realizaron las primeras exportaciones hacia los Estados Unidos de América (Muñoz, 2001). Tal fue el crecimiento del cultivo y de las exportaciones que en pocos años Loma Bonita alcanzó una fama internacional que le valió el nombre de la capital mundial de la piña (Traffano, 2012), la cual ha perdido al paso del tiempo.

Aunque en la actualidad el cultivo de piña en Loma Bonita ha disminuido su protagonismo frente a sus similares pertenecientes al estado de Veracruz, su siembra continúa siendo la principal actividad agrícola en este municipio, lo que se traduce en beneficios de tipo económico y social al representar una fuente de ingresos para los productores y sostén de sus familias, generación de empleos permanentes y eventuales en todo el proceso de producción que puede durar hasta 18 meses, la derrama económica que se genera durante el mismo y que dinamiza otras actividades económicas relacionadas con el abastecimiento de insumos, maquinaria, equipo, herramientas y servicios agrícolas, además de los procesos de industrialización y comercialización (OEIDRUS Oaxaca, 2009; Rebolledo, Uriza, del Ángel, Rebolledo, \& Zetina, 2011; Hernández \& Barrón, 2013).

No obstante, lo antes mencionado, en Loma Bonita son notorias las diferencias tecnológicas entre las unidades de producción de piña, lo que respaldaría lo señalado por algunos autores sobre la existencia en una misma región, municipio o localidad, en particular de múltiples formas de llevar a cabo la agricultura (Dufumier, 1990; Escobar \& Berdegué, 1990; Duch, 1998). De acuerdo con diversas aseveraciones, esto se debe a que en un espacio geográfico específico pueden converger agricultores 
the same technologies, or in their absence, although all have the interest, not all achieve this purpose due to the influence of multiple factors (economic, social, biophysical factors, etc.) (Aguilar, Muñoz, Santoyo, \& Aguilar, 2013; Cuevas et al., 2013; Vélez, Espinosa, Omaña, González, \& Quiroz, 2013; Vargas, Palacios, Camacho, Aguilar, \& Ocampo, 2015). For the purposes of this study, technological adoption is understood as the acquisition of services, supply of inputs and agricultural equipment offered in the market, as well as techniques and procedures incorporated by pineapple growers to the daily management of pineapple crop within their productive units (Cáceres, Silvetti, Soto, \& Rebolledo, 1997; Smith, 2002; Ortiz et al., 2013), in the municipality of Loma Bonita, Oaxaca.

In the literature it is possible to find theoretical studies classifying the units of production in multiple ways, from the simplest distinguishing them in peasant and enterprise (Duch, 1998), agricultural companies, growers in transition and, peasants (Solleiro, Del Valle, \& Lina,1003), to those that can include more specific typologies, which divide the peasant type into infra-subsistence, subsistence, stationary and surplus production units, and the business type into transitional, small agricultural enterprise, medium agricultural enterprise and large agricultural enterprise (Duch, 1998). While the empirical studies for agricultural production units have classified them into traditional, intermediate and entrepreneurial (Borja, Vélez, \& Ramos, 2018); very low, low, medium, high or very high technological level (Damián, et al., 2007; Leos, Serrano, Salas, Ramírez, \& Sagarnaga, 2008; Sánchez, Solorio, \& Santos, 2008; Cuevas et al., 2013; Hernández et al., 2013; Vélez et al, 2013; Sánchez, Zegbe, \& Gutiérrez, 2015; Cuevas, Loaiza, Espinosa, Vélez, \& Montoya, 2016; Pérez, Martínez, López, \& Rendón, 2016); business, transitional livestock, family farming, family livestock, and subsistence (Chalate et al, 2010); family subsistence without linkage to the market, family subsistence with linkage to the market, in transition, business with fragile profitability, thriving business and dynamic business (SAGARPA-FAO, 2012).

In general, these studies show that the larger the production units, the more available economic, productive, infrastructure and technological con el interés o no, en utilizar las mismas tecnologías, o en su defecto, aunque todos tengan el interés de hacerlo, no todos logran este propósito debido a la influencia de múltiples factores tanto económicos, sociales, biofísicos, etc. (Aguilar, Muñoz, Santoyo, \& Aguilar, 2013; Cuevas et al., 2013; Vélez, Espinosa, Omaña, González, \& Quiroz, 2013; Vargas, Palacios, Camacho, Aguilar, \& Ocampo, 2015). Para efectos del presente estudio, se entiende como adopción tecnológica la adquisición de servicios, suministro de insumos y equipos agrícolas que se ofertan en el mercado, así como de técnicas y procedimientos que son incorporadas por los piñeros al manejo cotidiano del cultivo de piña dentro de sus unidades productivas (Cáceres, Silvetti, Soto, \& Rebolledo, 1997; Smith, 2002; Ortiz et al., 2013), en el municipio de Loma Bonita Oaxaca.

En la literatura es posible encontrar estudios teóricos que clasifican las unidades de producción de múltiples formas, que van desde las más simples distinguiéndolas en tipo campesino y empresarial (Duch, 1998), empresas agrícolas, productores en transición y, campesinos (Solleiro, Del Valle, \& Lina, 1003), hasta aquellas que pueden incluir tipologías más específicas, que dividen a las de tipo campesino en unidades de producción de infrasubsistencia, de subsistencia, estacionarias $y$, excedentarias, y a las de tipo empresarial en transicional, pequeña empresa agrícola, mediana empresa agrícola y empresa agrícola grande (Duch, 1998). Mientras que los estudios empíricos para unidades de producción agropecuarias las han tipificado en tradicionales, intermedias y empresariales (Borja, Vélez, \& Ramos, 2018); nivel tecnológico muy bajo, bajo, medio, alto o muy alto (Damián, et al., 2007; Leos, Serrano, Salas, Ramírez, \& Sagarnaga, 2008; Sánchez, Solorio, \& Santos, 2008; Cuevas et al., 2013; Hernández et al., 2013; Vélez et al., 2013; Sánchez, Zegbe, \& Gutiérrez, 2015; Cuevas, Loaiza, Espinosa, Vélez, \& Montoya, 2016; Pérez, Martínez, López, \& Rendón, 2016); empresarial, de transición pecuaria, familiar agropecuaria, familiar pecuaria y, de subsistencia (Chalate et al., 2010); familiar de subsistencia sin vinculación al mercado, familiar de subsistencia con vinculación al mercado, en transición, empresarial con rentabilidad frágil, empresarial pujante y empresarial dinámico (SAGARPA-FAO, 2012). 
resources are, which is manifested in high levels of investment, but also in an increase in productivity and profitability by obtaining high yields and outstanding product quality. This, in turn, facilitates sales in the market, and, therefore, the achievement of higher incomes. On the contrary, growers or production units of low size, are regularly characterized by having small areas for agricultural activities, less availability of economic resources, limited technology, low production volumes, which makes it difficult to negotiate the price of products, directly impacting on low profitability.

Another aspect that stands out in the empirical studies analyzed is that classifications were carried out, where the components of the technological packages are partially considered (machinery, equipment, tools, services, methods, etc.). This agrees with the arguments of CIMMYT (1993); Luna et al. (2013); Vargas, Solís, Sáenz, and León (2013), that despite the wide range of studies on the subject in agricultural and livestock production units, the classification or typification has been carried out taking into account mostly socioeconomic characteristics such as availability of economic resources, land tenure or level of education, with the intention of explaining the differences between those who adopt technology and those who do not.

Under the arguments exposed, the present study has two objectives: 1) to classify the pineapple production units according to the technological level they have in the municipality of Loma Bonita, Oaxaca and 2) to describe the distinctive socioeconomic and technological characteristics of the production units. Making possible, as stated by Duch (1998), to know "the way in which growers carry out their work; the technological means they use for that purpose, as well as their scope and limitations; changes and innovations they introduce...,among other things. Similarly, the typification or classification of growers or their production units is considered as the first step to identify the factors causing variability in the technological levels of a given geographical space (Vélez et al., 2013) and serving as a basis for proposing public policy actions that impact on the support provided to growers, and thus improve their productive and economic conditions (Leos et al., 2008; Vélez et al., 2013; Sangermán, Larqué, Omaña, Shwenstesius, \& Navarro, 2014).
De manera general, se puede observar en estos trabajos que, a mayor tamaño de las unidades de producción, más disponibilidad de recursos tanto económicos, productivos, de infraestructura y tecnológicos, lo que se manifiesta en altos niveles de inversión, pero también en un aumento de la productividad y de la rentabilidad al obtener rendimientos elevados y sobresaliente calidad de los productos. Esto a su vez, facilita la venta en el mercado, $y$, por lo tanto, el logro de mayores ingresos. Por el contrario, los productores o unidades de producción de tamaños bajos, regularmente se caracterizan por contar con pequeñas superficies para las actividades agropecuarias, menor disponibilidad de recursos económicos, limitado nivel tecnológico, reducidos volúmenes de producción, lo que dificulta la negociación del precio de sus productos, repercutiendo directamente en una baja rentabilidad.

Otro de los aspectos que resalta en los trabajos empíricos analizados, es que llevan a cabo clasificaciones donde se consideran parcialmente los componentes de los paquetes tecnológicos (maquinaria, equipo, herramientas, servicios, métodos, etc.). Esto concuerda con lo argumentado por el CIMMYT (1993); Luna et al. (2013); Vargas, Solís, Sáenz, y León (2013), en torno a que, a pesar de la amplia gama de estudios sobre la temática en unidades de producción agrícolas y pecuarias, la clasificación o tipificación se han efectuado tomando en cuenta mayoritariamente características socioeconómicas como la disponibilidad de recursos económicos, la tenencia de la tierra o la escolaridad, con la intención de explicar las diferencias entre quienes adoptan la tecnología y quienes no lo hacen.

Bajo los argumentos expuestos, el presente trabajo tiene dos objetivos: 1) clasificar las unidades de producción de piña de acuerdo con el nivel tecnológico con el que cuentan en el municipio de Loma Bonita, Oaxaca y 2) describir las características socioeconómicas y tecnológicas distintivas de las unidades de producción. Esto permitirá como lo sostiene Duch (1998) conocer "la forma en que los productores realizan su trabajo; los medios tecnológicos que emplean para tal fin, así como sus alcances y limitaciones; los cambios e innovaciones que introducen..., entre otros aspectos. De igual forma, 


\section{Materials and methods}

The study was carried out in the municipality of Loma Bonita, located in the region of Papaloapan in the north of the state of Oaxaca, Mexico. It is located between the extreme geographic coordinates: north $18^{\circ} 10^{\prime}$ and south $17^{\circ} 46^{\prime}$ north latitude; east $95^{\circ} 47^{\prime}$ and west $95^{\circ} 59^{\prime}$ west longitude, at 30 masl. The agricultural sector in this municipality plays a very important role economically and socially, occupying in this type of activities little more than $35 \%$ of the economically active population, standing out in the agricultural production of pineapple, cane, maize, beans and pepper (Plan Municipal de Desarrollo, 2008-2010). It borders to the north and east with the state of Veracruz; to the south with the state of Veracruz and the municipalities of Santiago Jocotepec and San Juan Bautista Tuxtepec and to the west with the municipality of San Juan Bautista Tuxtepec (INEGI, 2005).

A survey was used as a data collection instrument, as it is a technique that has great advantages such as low cost of application, reaching a greater number of participants and facilitating the analysis of the information collected (Arribas, 2004; Hernández, Fernández, \& Baptista, 2010). The survey was composed of five socioeconomic variables related to the grower (age, level of education and experience) and his or her productive unit (area sown and type of land). As well as eight technological dimensions measured through 43 items of closed type, related to the activities and sources of income (3), specialized services (4), system and density of sowing (2), technification of activities (11), sowing variety MD2 or pineapple (1), amount of mechanical activities (6), availability of machinery and equipment (10), and amount of application of agrochemicals (6), which allowed to classify the levels of technological adoption.

The sampling technique was non-probabilistic, using "snowball" sampling, where the identification of some growers allowed access to other growers (Kleeberg \& Ramos, 2009), whose requirements to be study subjects were that they grow pineapple, regardless of the area they intended to cultivate and had the availability to be interviewed (Vilaboa et al., 2009). The final sample consisted of 68 growers. However, as recommended by Galindo, Tabares, la tipificación o clasificación de los productores o sus unidades de producción, se considera como el primer paso para identificar los factores que causan variabilidad en los niveles tecnológicos de un espacio geográfico determinado (Vélez et al., 2013) y que sirven como base para proponer acciones de política pública que impacten en los apoyos brindados a los productores, y con ello, mejorar sus condiciones productivas y económicas (Leos et al., 2008; Vélez et al., 2013; Sangermán, Larqué, Omaña, Shwenstesius, \& Navarro, 2014).

\section{Materiales y métodos}

El estudio se llevó a cabo en el municipio de Loma Bonita, localizado en la Región del Papaloapan al norte del estado de Oaxaca, México. Se ubica entre las coordenadas geográficas extremas: al norte $18^{\circ}$ $10^{\prime}$ y al sur $17^{\circ} 46^{\prime}$ de latitud norte; al este $95^{\circ} 47^{\prime}$ y al oeste $95^{\circ} 59^{\prime}$ de longitud oeste, a $30 \mathrm{msnm}$. El sector agropecuario en este municipio juega un papel muy importante económica y socialmente, ocupándose en este tipo de actividades poco más del $35 \%$ de la población económicamente activa, sobresaliendo en la producción agrícola los cultivos de piña, caña, maíz, fríjol y chile (Plan Municipal de Desarrollo, 2008-2010). Colinda al norte y al este con el estado de Veracruz; al sur con el estado de Veracruz y con los municipios de Santiago Jocotepec y San Juan Bautista Tuxtepec y al oeste con el municipio de San Juan Bautista Tuxtepec (INEGI, 2005).

Como instrumento de obtención de datos se utilizó el cuestionario, al ser una técnica que presenta grandes ventajas tales como su bajo costo de aplicación, permite llegar a un mayor número de participantes y facilita el análisis de la información recogida (Arribas, 2004; Hernández, Fernández, \& Baptista, 2010). El cuestionario quedó compuesto por cinco variables de tipo socioeconómico relacionadas con el productor (edad, escolaridad y experiencia) y su unidad productiva (superficie sembrada y tipo de terreno). Así como de ocho dimensiones tecnológicas medidas a través de 43 ítems de tipo cerrado, referentes con las actividades y fuentes de ingresos (3), servicios especializados (4), sistema y densidad de siembra (2), tecnificación de actividades (11), siembra de la variedad MD2 o piña miel (1), cantidad de actividades mecánicas (6), disponibilidad de 
and Gómez (2000) and Vargas et al. (2015), prior to the application of the final survey, a pilot test was carried out during the month of October 2016, which allowed the necessary adjustments to be made so that it could be easily answered by interviewees. The information was collected between December 2016 and April 2017.

To classify the pineapple production units in Loma Bonita, Oaxaca, according to the levels of technological adoption, Table 1, several studies related to the subject were taken as reference (Damián et al., 2007; Cuevas et al., 2013; Vargas et al., 2013), using interval, range and minimum and maximum limits statistics.

Thus, based on the eight technology components and respective 43 items, the data was captured in an Excel sheet and the interval and range were estimated, for which the minimum and maximum scores that appear in Table 1 were obtained from the number of items that made up each component and their corresponding scales. For example, the components 'activities and sources of income' were made up of three items and a total of 12 scales, so the minimum score was 3 and the maximum was 12; specialized services consisted of four items and eight scales, corresponding to a minimum score of 4 and a maximum of 8; and so on for the remaining dimensions.

The value of the interval was 140 points, while five levels of technology adoption were pre-established for the estimation of the range, so from 28-points (Table 1), the five pre-established levels of technology adoption with their subsequent limits were: Very low (43-70 points); Low (71-98 points); Medium (99-126 points); High (127-154 points) and Very high (155-183 points) (Damián et al., 2007; Cuevas et al., 2013).

\section{Results and discussion}

\section{Identification and classification of production units}

Based on the analysis carried out, of the 68 surveys applied, it was possible to classify four types of pineapple production units in the municipality of Loma Bonita, Oaxaca, according to the level of technological adoption: 1) Very low, 2) Low, 3) Medium and 4) High. Figure 1 shows that most of them co- maquinaria y equipo (10), y cantidad de aplicación de agroquímicos (6), que permitieron clasificar los niveles de adopción tecnológica.

La técnica de muestreo fue de tipo no probabilístico, empleándose el muestreo "bola de nieve", donde la identificación de algunos productores permitió acceder a otros productores (Kleeberg \& Ramos, 2009), cuyos requisitos para ser sujetos de estudio fueron que cultivaran piña, independientemente de la superficie que destinaran a ello y tuvieran la disponibilidad de ser entrevistados (Vilaboa et al., 2009). La muestra final quedó integrada por 68 productores. No obstante, tal como lo recomiendan Galindo, Tabares, y Gómez (2000) y Vargas et al. (2015), previo a la aplicación del cuestionario final, durante el mes de octubre de 2016 se realizó una prueba piloto que permitió hacer las adecuaciones necesarias para que pudiera ser contestado fácilmente por los entrevistados. La información se recabó entre los meses de diciembre de 2016 y abril de 2017.

Para clasificar las unidades de producción de piña de Loma Bonita, Oaxaca, de acuerdo con los niveles de adopción tecnológica, Cuadro 1, se tomaron como referencia diversos estudios relacionados con el tema (Damián et al., 2007; Cuevas et al., 2013; Vargas et al., 2013), empleando para ello, estadísticos de intervalo, rango y límites mínimos y máximos.

De esta manera, con base en los ocho componentes tecnológicos y sus respectivos 43 ítems, los datos se capturaron en una hoja de Excel y se calcularon el intervalo y el rango, para lo cual las puntuaciones mínimas y máximas que aparecen en el Cuadro 1 se obtuvieron a partir del número de ítems que conformaron cada componente y sus escalas correspondientes, por ejemplo, el componente actividades y fuentes de ingresos estuvo integrada por tres ítems y un total de 12 escalas, por lo que la puntuación mínima fue de 3 y la máxima de 12 puntos; los servicios especializados quedaron conformados por cuatro ítems y ocho escalas, correspondiendo a la puntuación mínima de 4 y máxima de 8 ; y así sucesivamente para el resto de las dimensiones.

El valor del intervalo fue de 140 puntos, mientras que para el cálculo del rango se preestablecieron cinco niveles de adopción tecnológica, por lo que 
Table 1. Estimation of the range to determine technology adoption levels Cuadro 1. Cálculo del rango para determinar los niveles de adopción tecnológica

\begin{tabular}{|c|c|c|c|}
\hline \multirow{2}{*}{ No. } & \multirow{2}{*}{ Components / Componentes } & \multicolumn{2}{|c|}{ Score / Puntuación } \\
\hline & & Min & Max \\
\hline 1 & Activities and sources of income / Actividades y fuentes de ingresos & 3 & 12 \\
\hline 2 & Specialized services / Servicios especializados & 4 & 8 \\
\hline 3 & Sowing system and density / Sistema y densidad de siembra & 2 & 8 \\
\hline 4 & Technification of activities / Tecnificación de actividades & 11 & 43 \\
\hline 5 & Sowing variety MD2 / Siembra de la variedad MD2 & 1 & 6 \\
\hline 6 & Number of mechanical activities / Cantidad de actividades mecánicas & 6 & 30 \\
\hline 7 & Availability of machinery and equipment / Disponibilidad de maquinaria y equipo & 10 & 40 \\
\hline \multirow[t]{4}{*}{8} & Quantity of agrochemical application / Cantidad de aplicación de agroquímicos & 6 & 36 \\
\hline & TOTAL & 43 & 183 \\
\hline & INTERVAL / Intervalo & \multicolumn{2}{|c|}{$\begin{array}{l}183-43=140 \text { points } / 183- \\
43=140 \text { puntos }\end{array}$} \\
\hline & RANGE / Rango & \multicolumn{2}{|c|}{28 points / 28 puntos } \\
\hline
\end{tabular}

Source: Compiled by the author. / Fuente: Elaboración propia.

rrespond to the low and medium level where more than $91 \%$ of the productive units are concentrated. It should be noted that $38(55.9 \%)$ have a low level of technological adoption, 24 (35.3\%) are located with a medium level of adoption. In a lower percentage are the very low and high levels with three growers corresponding to $4.4 \%$ respectively. It is worth mentioning the absence of growers with a very high technological level, which means that there are no pineapple growers who use or tend to apply total services, inputs, techniques, procedures and equipment offered in the market.

The results are consistent with the findings of Pérez et al. (2016), who, from a package of 29 innovative practices, identified the same level for a sample of 552 rural maize producers in the state of Guerrero. They are also similar to what was reported by Borja et al. (2018), distinguishing three groups of guava growers in the state of Aguascalientes, Mexico, from a sample of 91 production units, highlighting a wide concentration of traditional (53.8\%); intermediate (34.1\%) and business (12.1\%) growers. Other authors reporting similar results are Cuevas et al. (2013) and Rocha, Mora, and Romero (2016).

Regarding the existence of few growers with high technological or business levels, there are positions that indicate that it is a reflection of the economic development model of globalization a partir del rubro de 28 puntos del rango (Cuadro 1), los cinco niveles de adopción tecnológica preestablecidos con sus subsecuentes límites fueron: Muy bajo (43-70 puntos); Bajo (71-98 puntos); Medio (99-126 puntos); Alto (127-154 puntos) y Muy alto (155-183 puntos) (Damián et al., 2007; Cuevas et al., 2013).

\section{Resultados y discusión}

\section{Identificación y clasificación de las unidades de producción}

Con base en el análisis llevado a cabo, de las 68 encuestas aplicadas, fue posible clasificar cuatro tipos de unidades de producción de piña en el municipio de Loma Bonita, Oaxaca, de acuerdo con el nivel de adopción tecnológica: 1) Muy bajo, 2) Bajo, 3) Medio y 4) Alto. En la Figura 1 se puede observar que la mayor parte corresponde a los estratos bajo y medio donde se concentran más del $91 \%$ de las unidades productivas. Destaca que 38 (55.9 \%) cuentan con un nivel de adopción tecnológico bajo, 24 (35.3\%) se ubican con un nivel de adopción medio. En menor porcentaje se encuentran los niveles muy bajo y alto con tres productores correspondientes al $4.4 \%$ respectivamente. Cabe mencionar la ausencia de productores con nivel tecnológico muy alto, lo que significa que no existen piñeros que utilicen 
Figure 1. Levels of technological adoption of pineapple production units in Loma Bonita, Oaxaca

Figura 1. Niveles de adopción tecnológica de las unidades de producción de piña en Loma Bonita, Oaxaca

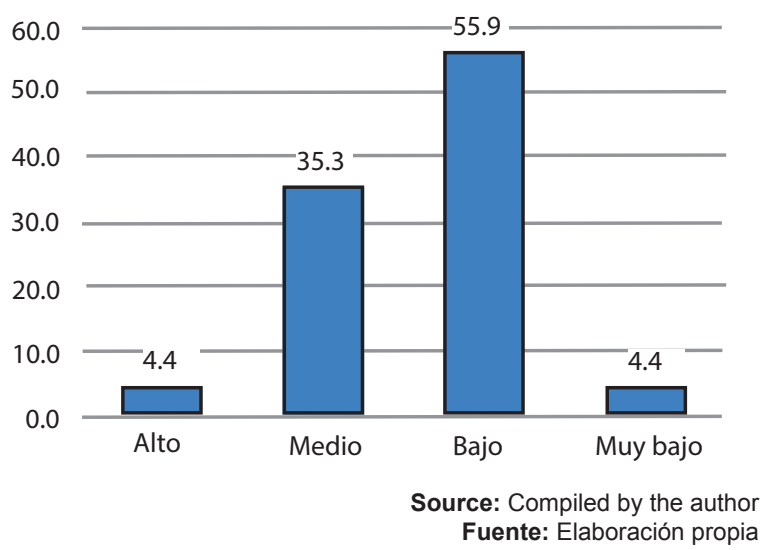

and trade opening based on competitiveness, where only those growers who are able to innovate and adapt to the circumstances dictated by the market, can achieve greater economic benefits. In this regard, Gil and Vivar (2015) mention that this development model is gradually, causing inequality and backwardness among growers. These positions are debatable since there is evidence that before the implementation of the "neoliberal model" there were already asymmetries between growers. In fact, it is considered that the problem of growers with low technological levels may be their inability to adapt to market needs, since at present time some small growers have achieved certifications that allow them to compete in international markets by serving specific, but very profitable niches.

On the other hand, the results of this study differ from those reported by Velez et al. (2013) who classified three technological levels for 248 family dairy producers in the state of Guanajuato, Mexico, based on the use of 25 technologies. The respective percentages were located in the ranges of low technological level (10.9\%), medium technological level (29.4\%) and high technological level (59.7\%). This could be associated to the fact that their study was carried out considering producers who participated in a government program of technical assistance and training. In this sense, there is empirical evidence that points to a direct relationship between technical assistance and training that producers receive with the level of o tiendan a aplicar el total de servicios, insumos, técnicas, procedimientos y equipos ofertados en el mercado.

Los resultados concuerdan con los hallazgos de Pérez et al. (2016), quienes a partir de un paquete de 29 prácticas innovadoras identificaron los mismos estratos para una muestra de 552 productores rurales de maíz en el estado de Guerrero. También son similares con lo reportado por Borja et al. (2018), distinguiendo tres grupos de productores de guayaba en el estado de Aguascalientes, México, a partir de una muestra de 91 unidades de producción, destacando una amplia concentración en productores tradicionales (53.8\%); intermedios (34.1\%) y empresariales (12.1\%). Otros autores que reportan resultados semejantes son Cuevas et al. (2013) y Rocha, Mora, y Romero (2016).

Sobre la existencia de pocos productores con niveles tecnológicos altos o empresariales, existen posturas que señalan que es un reflejo del modelo de desarrollo económico de globalización y apertura comercial basado en la competitividad, donde solo aquellos productores que sean capaces de innovar y adaptarse a las circunstancias que dicta el mercado, pueden lograr mayores beneficios económicos. Sobre esto, Gil y Vivar (2015) mencionan que este modelo de desarrollo poco a poco va provocando una desigualdad y rezago entre productores. Estas posturas son debatibles al existir evidencias de que antes de la implantación del "modelo neoliberal" ya había asimetrías entre productores, de hecho, se considera que el problema de los productores con bajos niveles tecnológicos puede estar en su incapacidad de adaptación a las necesidades del mercado, ya que en la actualidad algunos pequeños productores han logrado certificaciones que les permite competir en mercados internacionales atendiendo nichos específicos, pero muy rentables.

Por otro lado, los resultados de este trabajo difieren de los reportados por Vélez et al. (2013) quienes clasificaron tres niveles tecnológicos para 248 productores de lechería familiar en el estado de Guanajuato, México, a partir del uso de 25 tecnologías. Los porcentajes respectivos se ubicaron en los rangos de nivel tecnológico bajo (10.9\%), nivel tecnológico medio (29.4\%) y nivel tecnológico alto (59.7\%). Esto podría estar asociado a que su 
technological adoption achieved in their production units (Velasco, Ortega, Sánchez, \& Urdaneta, 2009; Cuevas et al., 2013; Vélez et al., 2013; Vargas et al., 2015).

\section{Socioeconomic characteristics}

From the socioeconomic characteristics summarized in Table 2, it was obtained that for the 68 producers surveyed, the average age was 48 \pm 11.274 years with a minimum of 20 and a maximum of 75 years. The mean is within the age range of the population engaged in agricultural activities in Mexico reported by the Ministry of Agriculture, Livestock, Rural Development, Fisheries and Food and the Food and Agriculture Organization of the United Nations (SAGARPA-FAO, 2014) which ranges from 42 to 56 years. Similarly, it is below the age of 50 that these same institutions use to differentiate the estudio se llevó a cabo considerando productores que participaron en un programa gubernamental de asistencia técnica y capacitación. En este sentido, existen evidencias empíricas que señalan una relación directa entre la asistencia técnica y la capacitación que reciben los productores con el nivel de adopción tecnológica logrado en sus unidades de producción (Velasco, Ortega, Sánchez, \&Urdaneta, 2009; Cuevas et al., 2013; Vélez et al., 2013; Vargas et al., 2015).

\section{Características socioeconómicas}

De las características socioeconómicas las cuales se resumen en el Cuadro 2, se obtuvo que de los 68 productores encuestados la edad promedio se ubicó en $48 \pm 11.274$ años con una mínima de 20 y máxima de 75 años. La media se encuentra dentro del rango de edad de la población que se dedica a actividades

Table 2. Socioeconomic characteristics of pineapple growers in Loma Bonita, Oaxaca per level of technology adoption

Cuadro 2. Características socioeconómicas de los productores de piña de Loma Bonita, Oaxaca por nivel de adopción tecnológica

\begin{tabular}{|c|c|c|c|c|c|c|}
\hline \multirow{2}{*}{$\begin{array}{l}\text { Caracteristic / } \\
\text { Característica }\end{array}$} & \multirow[t]{2}{*}{ Scala / Escala } & \multicolumn{5}{|c|}{ Technological level / Nivel tecnológico } \\
\hline & & $\begin{array}{c}\text { General } \\
(\%)\end{array}$ & $\begin{array}{l}\text { Very low (\%)/ } \\
\text { Muy bajo \% }\end{array}$ & $\begin{array}{l}\text { Low (\%)/ } \\
\text { Bajo (\%) }\end{array}$ & $\begin{array}{l}\text { Medium (\%)/ } \\
\text { Medio(\%) }\end{array}$ & $\begin{array}{l}\text { High (\%)/ } \\
\text { Alto (\%) }\end{array}$ \\
\hline \multirow[t]{2}{*}{ Age/Edad } & $\leq 50$ years $/ 50$ años & 52.9 & 0.0 & 52.6 & 58.3 & 0.0 \\
\hline & $>50$ years / 50 años & 47.1 & 100 & 47.4 & 41.7 & 100 \\
\hline \multirow{5}{*}{$\begin{array}{l}\text { Level of education/ } \\
\text { Escolaridad }\end{array}$} & Uneducated / Sin estudios & 4.4 & 33.3 & 2.6 & 0.0 & 33.3 \\
\hline & Elementary school/Primaria & 23.5 & 0.0 & 26.3 & 20.8 & 33.3 \\
\hline & Junior high school/Secundaria & 17.6 & 33.3 & 21.1 & 8.3 & 33.3 \\
\hline & High school/Bachillerato & 26.5 & 33.3 & 23.7 & 33.3 & 0.0 \\
\hline & University/Licenciatura & 27.9 & 0.0 & 26.3 & 37.5 & 0.0 \\
\hline \multirow{4}{*}{$\begin{array}{l}\text { Experience/ } \\
\text { Experiencia }\end{array}$} & $\leq 5$ years $/ \leq$ de 5 años & 16.2 & 66.7 & 10.5 & 20.8 & 0.0 \\
\hline & $\begin{array}{l}>5 \text { years but } \leq 10 \text { years/ } \\
>\text { de } 5 \text { pero } \leq \text { de } 10 \text { años }\end{array}$ & 29.4 & 0.0 & 39.5 & 20.8 & 0.0 \\
\hline & $\begin{array}{l}>10 \text { years but } \leq 15 \text { years } \\
>\text { de } 10 \text { pero } \leq \text { de } 15 \text { años }\end{array}$ & 22.1 & 33.3 & 26.3 & 20.8 & 0.0 \\
\hline & $>15$ years $/>$ de 15 años & 32.4 & 0.0 & 23.7 & 37.5 & 100 \\
\hline \multirow{5}{*}{$\begin{array}{l}\text { Area sown/ } \\
\text { Superficie sembrada }\end{array}$} & $\leq 5 \mathrm{ha} / \leq$ de $5 \mathrm{ha} />$ de 5 pero $\leq$ de $15 \mathrm{ha}$ & 38.2 & 100 & 52.7 & 12.5 & 0.0 \\
\hline & $>5$ ha but $\leq 15$ ha $/>5$ ha pero $\leq 15$ ha & 33.8 & 0.0 & 39.5 & 33.3 & 0.0 \\
\hline & $>15$ ha but $\leq 30$ ha $/>15$ ha pero $\leq 30$ ha & 16.2 & 0.0 & 7.9 & 33.3 & 0.0 \\
\hline & $>30$ ha but $\leq 50$ ha $/>30$ ha but $\leq 50$ ha & 8.8 & 0.0 & 0.0 & 16.7 & 67.0 \\
\hline & $>50 \mathrm{ha} />$ de $50 \mathrm{ha}$ & 2.9 & 0.0 & 0.0 & 4.2 & 33.0 \\
\hline \multirow{4}{*}{$\begin{array}{l}\text { Type of land/ } \\
\text { Tipo de terreno }\end{array}$} & On loan/Prestado & 4.4 & 0.0 & 5.3 & 4.2 & 0.0 \\
\hline & Leased/Arrendado & 32.4 & 33.0 & 42.1 & 20.8 & 0.0 \\
\hline & Own/Propio & 48.5 & 67.0 & 39.5 & 58.3 & 67.0 \\
\hline & Own and leased/Propio y arrendado & 14.7 & 0.0 & 13.2 & 16.7 & 33.0 \\
\hline
\end{tabular}

Source: Compiled by the author / Fuente: Elaboración propia 
young rural population (up to 50 years old) from the old population (over 50 years old).

It is worth mentioning that the average age of growers with low and medium level of technological adoption was 45.8 and 48.3 years respectively, which places them as young growers. The percentages for growers up to 50 years old in both ranges exceed $50 \%$. This data is important because there are studies that show that when growers are younger, it is feasible that they adopt more easily the available technology, affecting the achievement of higher technological levels (Rojas 1998; Vicini, 2000; Walter, 2007; Aguilar et al., 2013; Cuevas et al., 2013; Vélez et al., 2013), so future studies should consider the relationship between age and level of technological adoption.

As to the level of education of pineapple growers, a large percentage stands out, which has higher and middle schooling representing 54.4\%, 27.9\% corresponds to those with bachelor studies, and $26.5 \%$ to those with high school or technical studies. The remaining $45.6 \%$ was distributed among primary studies with $23.5 \%$; secondary with $17.6 \%$ and $4.4 \%$ without studies. By level of technological adoption, the low and medium levels also concentrate large percentages of growers with high school and university degrees, while producers with very low and high levels have representative percentages with low levels of schooling (Table 2). The relevance of these numbers lies in the fact that there are studies that show that the level of education of growers is positively related to the level of technological adoption (Walter, 2007; Velasco, et al., 2009; Aguilar et al., 2013; Cuevas et al., 2013; Vélez et al., 2013), so it would be relevant for future research on pineapple to include an analysis of the relationship between these two variables.

Regarding the experience in pineapple crop measured through the years of engaging in the activity, $32.4 \%$ said to have more than 15 years of experience, $29.4 \%$ said to have more than five and up to 10 years, $22.1 \%$ more than 10 and up to 15 years, complementing with $16.2 \%$ with up to five years in production. By rank, it highlights that $50 \%$ of growers in the low level and $58.3 \%$ in the middle level have more than 10 years of experience, and in the case of high level, the total of growers exceed 15 years (Table 2). In this case, there are those who mention that the greater the ex- agropecuarias en México reportado por la Secretaría de Agricultura, Ganadería, Desarrollo Rural, Pesca y Alimentación y la Organización de las Naciones Unidas para la Alimentación y la Agricultura (SAGARPA-FAO, 2014) que va de los 42 a los 56 años. De igual manera, está por debajo de los 50 años que estas mismas instituciones emplean para diferenciar la población rural joven (hasta 50 años) de la población vieja (mayores de 50 años).

Cabe mencionar que la edad promedio de los productores con nivel de adopción tecnológica bajo y medio fue de 45.8 y 48.3 años respectivamente, lo que los ubica como productores jóvenes. Los porcentajes para productores de hasta 50 años en ambos rangos superan el $50 \%$. Estos datos son importantes debido a que existen estudios que muestran que cuando los productores son más jóvenes, es factible que adopten con mayor facilidad la tecnología disponible, repercutiendo en el logro de mayores niveles tecnológicos (Rojas 1998; Vicini, 2000; Walter, 2007; Aguilar et al., 2013; Cuevas et al., 2013; Vélez et al., 2013), por lo que futuros estudios deberán contemplar la relación entre la edad y el nivel de adopción tecnológica.

En cuanto al nivel de estudios de los piñeros, destaca un amplio porcentaje que cuenta con escolaridad media superior y superior que representan el $54.4 \%$, correspondiendo a aquellos con estudios de licenciatura un $27.9 \%$ y de bachillerato o técnica el 26.5 $\%$. El $45.6 \%$ restante se distribuyó entre estudios de primaria con $23.5 \%$; secundaria con $17.6 \%$ y sin estudios con $4.4 \%$. Por nivel de adopción tecnológica los niveles bajo y medio también concentran amplios porcentajes de productores con escolaridad de bachillerato y licenciatura, mientras que los productores con niveles muy bajo y alto presentan porcentajes representativos con bajos niveles escolares (Cuadro 2). La relevancia de estas cifras radica en que existen trabajos que demuestran que el nivel de estudios de los productores se relaciona positivamente con el nivel de adopción tecnológica (Walter, 2007; Velasco, et al., 2009; Aguilar et al., 2013; Cuevas et al., 2013; Vélez et al., 2013), por lo que sería pertinente para futuras investigaciones sobre piña, incluir un análisis de la relación entre estas dos variables.

Con respecto a la experiencia en el cultivo de la piña medida a través de los años de dedicarse a la ac- 
perience, the higher the level of adoption of innovations (Aguilar et al., 2013).

On the other hand, the data indicated that the percentages of the number of growers decrease as the area sown increases. Thus, $38.2 \%$ indicated to sow up to five hectares, followed by those growers that sow between five and 15 hectares (33.8\%), $16.2 \%$ indicated to cultivate from 15 to 30 hectares. In lower proportion were located those who sow from 30 to 50 hectares with $8.8 \%$ and more than 50 hectares with only $2.9 \%$ of the sample. By ranges it stands out that $100 \%$ of growers with very low level of technology adoption have areas that do not exceed five hectares, the low level reports $39.5 \%$ of growers with areas between 5 and 15 hectares and 7.9\% between 15 and 30 hectares. From the medium level it is possible to find growers with above 30 hectares sowed, including some exceeding 50 hectares (Table 2). Various studies have shown that growers with large areas of cultivation are more likely to have production units with a higher level of technology, which may be due to the fact that they have a great capacity for capital investment, take advantage of economies of scale and have easy access to credit, aspects that facilitate the incorporation of technological practices and increase productivity (Rojas, 1998; Vicini, 2000; Molina \& Álvarez 2009; Velasco et al., 2009; García, Aguilar, \& Bernal, 2011; Vargas et al., 2015).

Finally, the land on which growers sow pineapple in $48.5 \%$ of cases is their own followed by $32.4 \%$ who lease it, while $14.7 \%$ said to sow on land both owned and leased and the remaining 4.4\% said the land is on loan. By technological level, in all cases, there are large percentages of growers with own land, as well as growers who, in addition to having their own land, have the possibility of leasing more surface area to expand their productive capacity, even those with a low level of technological adoption (Table 2). In this case, there is evidence that land tenure is an important factor in explaining adoption, with a greater use of technologies if the grower is the owner (Martínez \& Gómez, 2012), while growers who lease land present clear difficulties when making investment decisions when it comes to technology adoption (Molina \& Álvarez, 2009). tividad, un 32.4 \% señaló contar con más de 15 años de experiencia, $29.4 \%$ manifestó tener más de cinco y hasta 10 años, $22.1 \%$ más de 10 y hasta 15 años, complementando con el $16.2 \%$ con hasta cinco años en la producción. Por rangos, destaca que $50 \%$ de los productores del nivel bajo y $58.3 \%$ del nivel medio cuentan con más de 10 años de experiencia, y en el caso del nivel alto el total de los productores superan los 15 años (Cuadro 2). Para este caso hay quienes mencionan que, a mayor experiencia el nivel de adopción de innovaciones se incrementa (Aguilar et al., 2013).

Por otro lado, los datos indicaron que los porcentajes del número de productores disminuye conforme la superficie sembrada aumenta. Así, un $38.2 \%$ señaló sembrar hasta cinco hectáreas, seguido de aquellos productores que siembran entre cinco y 15 hectáreas (33.8\%), $16.2 \%$ indicó cultivar de 15 a 30 hectáreas. En menor porcentaje se ubicaron los que siembran de 30 a 50 hectáreas con $8.8 \%$ y más de 50 hectáreas con solo el $2.9 \%$ de la muestra. Por rangos sobresale que el $100 \%$ de los productores con muy bajo nivel de adopción tecnológica cuentan con superficies que no superan las cinco hectáreas, el nivel bajo reporta $39.5 \%$ de productores con superficie entre 5 y 15 hectáreas y $7.9 \%$ entre 15 y 30 hectáreas. A partir del nivel medio es posible encontrar productores con superficies sembradas por encima de las 30 hectáreas, incluso algunos que superan las 50 hectáreas (Cuadro 2). Diversos estudios han demostrado que productores con amplias áreas de cultivo tienen más probabilidad de contar con unidades de producción con mayor nivel tecnológico, lo cual se puede deber a que cuentan con gran capacidad de inversión de capital, aprovechan economías de escala y tienen facilidad para acceder al crédito, aspectos que facilitan incorporar prácticas tecnológicas e incrementar la productividad (Rojas, 1998; Vicini, 2000; Molina \& Álvarez 2009; Velasco et al., 2009; García, Aguilar, \& Bernal, 2011; Vargas et al., 2015).

Por último, el tipo de terreno en el que los productores siembran la piña en un $48.5 \%$ de los casos es propio, seguido de aquellos que lo rentan con un $32.4 \%$, mientras que el $14.7 \%$ señaló sembrar en terrenos tanto propios como arrendados y el 4.4 $\%$ restante manifestó que es prestado. Por niveles tecnológicos, destacan en todos los casos amplios porcentajes con productores con terreno propio, 


\section{Technological characteristics}

In order to describe the activities and sources of income of pineapple growers in the municipality of Loma Bonita, Oaxaca, the following were considered: a) labor or economic activities other than agriculture and livestock to which the grower is engaged, $b$ ) the percentage of the producer's income that depends on agriculture, and c) percentage of income from cattle farming. For the first case, $61.8 \%$ indicated that they were dedicated to other activities in addition to pineapple crops, hired as temporary employees, had a permanent job or owned a business (Figure 2). This large percentage contributes to the statements that sustain that given the fall in profitability of agricultural activities, many growers have seen their income decrease, so they take the decision to work outside the land in order to increase their income and meet various needs (Ávila, 2001; Molina \& Álvarez, 2009).

Regarding the percentage of income depending on agriculture, it is worth noting that $41.2 \%$ of the growers indicated that their income depends more than $50 \%$ but less than $100 \%$, while $19.1 \%$ of the pineapple growers stated that their income depends more than $100 \%$. In the same way, when asked about the percentage of the producer's income that depends on cattle farming, the highest number corresponded to nothing with $64.7 \%$ and, the remaining $35.3 \%$ stated that in some percentage that goes from $10 \%$ to those whose income depends on more than $50 \%$ (Figure 2).

These numbers reflect the agricultural orientation of the municipality of Loma Bonita, particularly pineapple crops and, therefore, the socioeconomic importance it has within the municipality. Similarly, the fact that a significant percentage of growers in Loma Bonita combine pineapple crop with cattle farming may be an indication of what was established by Cih-Dzul, Jaramillo, Tornero, and Schwentesius (2011) for whom the constant increase in the price of agricultural inputs leads farmers to employ production diversification as a strategy to ensure income.

In recent years, soil and water analysis services have been incorporated into the pineapple production process, as well as technical assistance, either on an occasional or permanent basis. Only así como productores que además de disponer con terreno propio cuentan con la posibilidad de arrendar más superficie para ampliar su capacidad productiva, incluso de aquellos con bajo nivel de adopción tecnológica (Cuadro 2). En este caso, existen evidencias que la tenencia de la tierra es un factor importante en la explicación de la adopción, notándose una mayor utilización de tecnologías si el productor es propietario (Martínez \& Gómez, 2012), mientras que los productores que rentan terreno presentan claras dificultades al momento de tomar decisiones de inversión cuando de adopción tecnológica se trata (Molina \& Álvarez, 2009).

\section{Características tecnológicas}

Para describir las actividades y fuentes de ingresos por parte de los productores de piña del municipio de Loma Bonita, Oaxaca se consideraron: a) las actividades laborales o económicas diferentes a la agricultura y ganadería a las que se dedica el productor, b) el porcentaje de los ingresos del productor que dependen de la agricultura $y, c$ ) el porcentaje de ingresos provenientes de la ganadería bovina. Para el primer caso, el 61.8 \% señalaron dedicarse a otras actividades adicionales al cultivo de la piña al contratarse como asalariados eventuales, contar con un trabajo fijo o ser propietario de un

Figure 2. Percentage of income of pineapple growers who depend on agriculture and livestock in Loma Bonita, Oaxaca

Figura 2. Porcentaje de ingresos de los productores de piña que dependen de la agricultura y la ganadería en Loma Bonita, Oaxaca

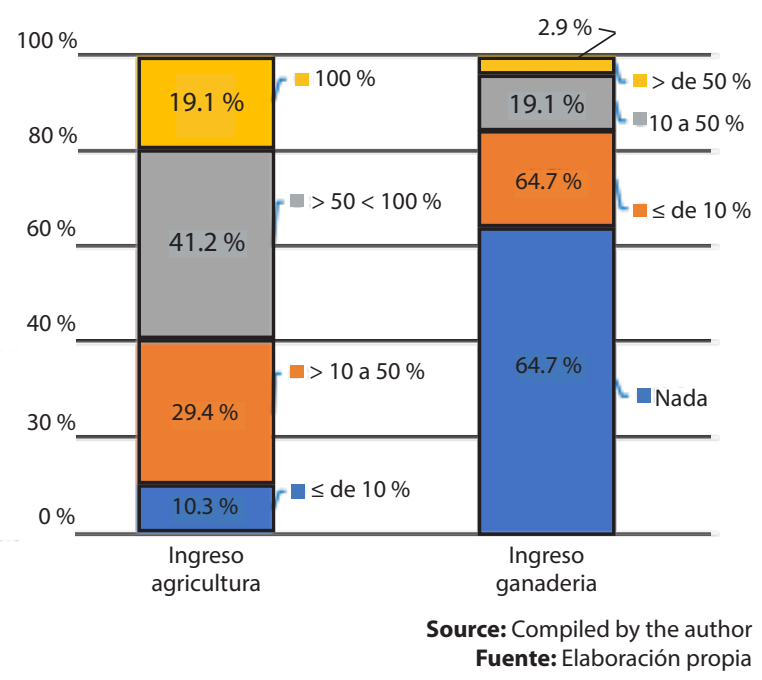


$29.4 \%$ of those surveyed indicated that they carry out soil analysis, $22.1 \%$ carry out water analysis, $29.4 \%$ hire technical assistance eventually, especially on issues of application of agrochemicals and $19.1 \%$ have a permanent field technician. By technological level, low percentages of adoption are observed in the four technological components integrating the specialized services, being 'hiring technical assistance' the most used (Table 3). This coincides with that mentioned by Pérez et al. (2016) for whom contracting this type of service can only be carried out by a few growers with financial capacity, conditioning its adoption.

The system and density of sowing become more relevant, since the greater the number of plants sown negocio (Figura 2). Este amplio porcentaje abona a los señalamientos que sostienen que, ante la caída de la rentabilidad de las actividades agrícolas, muchos productores han visto disminuido su ingreso, por lo que toman la decisión de asalariarse fuera del predio con el objetivo de incrementarlos y hacer frente a diversas necesidades (Ávila, 2001; Molina \& Álvarez, 2009).

Referente al cuestionamiento sobre el porcentaje de los ingresos que dependen de la agricultura, destaca que un $41.2 \%$ de los productores indicó que más del $50 \%$ pero menos del $100 \%$, mientras que el 19.1 $\%$ de los piñeros manifestó que el $100 \%$. De la misma manera, a la pregunta del porcentaje del ingreso del productor que depende de la ganadería bovina,

Table 3. Contracting of services, system and density of sowing in pineapple crops in Loma Bonita, Oaxaca, per level of technological adoptionCuadro

Cuadro 3. Contratación de servicios, sistema y densidad de siembra en cultivo de piña en Loma Bonita, Oaxaca, por nivel de adopción tecnológica

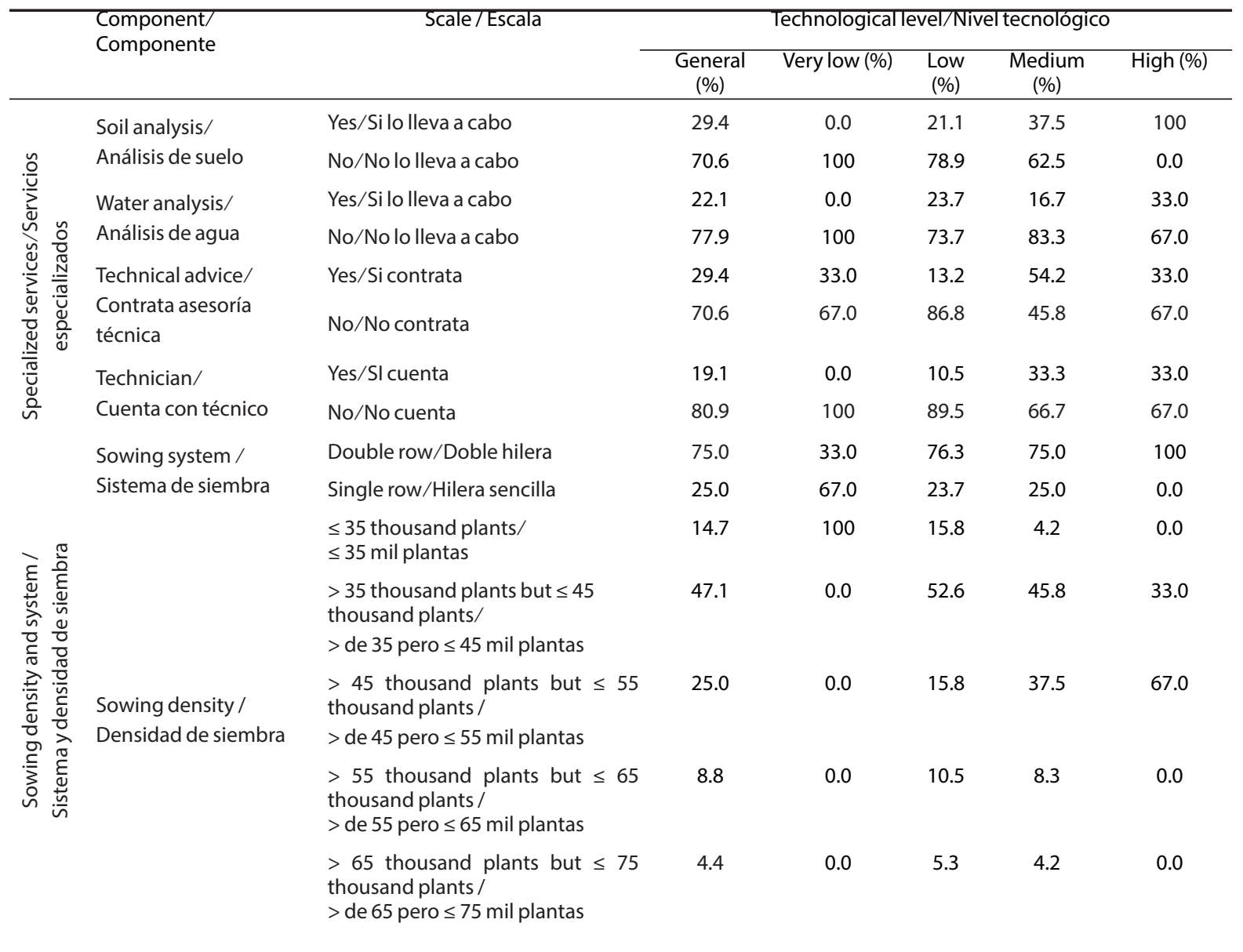


per hectare, the costs of both the acquisition of seed (scions) and maintenance increase. In this sense, the system of sowing in double row is the most used at present time in $75 \%$ and, the remaining $25 \%$ is sown in single row. It is worth mentioning that the four levels of technology adoption have adopted important percentages, the double-row sowing, especially in the low, medium levels. In contrast, the very low level is oriented to single-row production and the high level to double-row only (Table3).

Sowing density per hectare was concentrated in two ranges corresponding to $47.1 \%$ to more than 35 thousand plants and up to 45 thousand plants, followed by more than 45 thousand plants and up to 55 thousand plants with $25 \%$. Together both sowing densities represented more than $72 \%$. The complementary percentage was distributed in other densities. The lowest density of sowing (up to 35 thousand plants) is presented in growers with low technological adoption level, while most of the growers with low and medium levels sow from 35 thousand and up to 45 thousand plants, while a relevant percentage of the high level sow from 45 thousand and up to 55 thousand plants (Table3). In relation to this, growers with very low and low level of technological adoption when sowing in small areas with lower density of plants per hectare, as well as little or no incorporation of other technologies that contribute to harvest better quality fruits such as shade mesh, mulching and irrigation systems, are very likely to obtain low yields per hectare, lower volume of production and poor quality, so that at the time of marketing are at a disadvantage in negotiating better prices with intermediaries, resulting in lower incomes, profitability and ability to access credit, which in turn hinders reinvestment in the sowing of larger areas and the acquisition of new technologies.

To measure the technification of the activities that are carried out from the preparation of the land until the fruit is ready to be harvested, the use of machinery and equipment moved mechanically, as well as implements and tools moved through the physical force of man, were considered. In this case, it should be noted that land preparation, which may include weeding chapeo (weeding with cutter or a machete), harrowing, fallowing, levelling, furrowing, etc., is carried out in $44.1 \%$ of the cases exclusively la mayor cifra correspondió a nada con un $64.7 \%$ y, el $35.3 \%$ restante sostuvo que en algún porcentaje que va del $10 \%$ hasta aquellos cuyo ingreso depende en más del $50 \%$ (Figura 2).

Estos rubros reflejan la orientación hacia la agricultura del municipio de Loma Bonita, particularmente al cultivo de la piña y, por lo tanto, de la importancia socioeconómica que este tiene dentro del municipio. De igual forma el hecho de que un porcentaje importante de los productores de Loma Bonita combinen el cultivo de piña con la producción bovina, puede ser un indicativo de lo establecido por Cih-Dzul, Jaramillo, Tornero, y Schwentesius (2011) para quienes el incremento constante del precio de los insumos agrícolas orilla a los agricultores a emplear como estrategia, la diversificación productiva para garantizar la obtención de ingresos.

En años recientes se han incorporado al proceso de producción de piña servicios de análisis de suelo y agua, así como la contratación de asesoría técnica, ya sea en forma eventual o permanente. Sobre esto, solo el $29.4 \%$ de los encuestados señaló llevar a cabo análisis de suelos, $22.1 \%$ realiza análisis de agua, 29.4 $\%$ contrata asesoría técnica eventualmente, sobre todo, en temas de aplicación de agroquímicos y 19.1 \% cuenta con técnico de campo en forma permanente. Por nivel tecnológico se observan bajos porcentajes de adopción en los cuatro componentes tecnológicos que integran los servicios especializados, siendo la contratación de asesoría técnica la más recurrida en todos los estratos (Cuadro 3). Esto coincide con lo mencionado por Pérez et al. (2016) para quienes la contratación de este tipo de servicios, solo lo pueden llevar a cabo pocos productores con capacidad financiera, lo que condiciona su adopción.

El sistema y la densidad de siembra toman relevancia toda vez que, a mayor número de plantas sembradas por hectárea, los costos tanto de adquisición de semilla (hijuelos) y de mantenimiento se incrementan. En este sentido, el sistema de siembra en la doble hilera es el que más se emplea en la actualidad en un $75 \%$ y, el $25 \%$ restante se siembra en hilera sencilla. Cabe mencionar que los cuatro niveles de adopción tecnológica han adoptado porcentajes importantes, la siembra a doble hilera, sobre todo en los niveles bajo, medio. Por el contrario, el nivel muy bajo se orienta a la producción en hilera sencilla y el 
mechanically, in $42.6 \%$ manual and mechanical activities are combined, and only $13.2 \%$ are carried out manually. In addition, it can be seen that medium and high levels are the ones who carry out the most of these activities in a mechanical manner (Table 4).

In the case of liquid application of different agrochemicals such as fertilizers, pesticides, ripening regulators, fungicides, floral induction products, such as weed control, the levels of adoption of mechanical technology such as spray boom and mowers are low, with numbers that do not exceed $30 \%$, medium and high levels are those that make nivel alto exclusivamente a la doble hilera (Cuadro 3).

La densidad de siembra por hectárea se concentró en dos rangos correspondiendo al $47.1 \%$ a más de 35 y hasta 45 mil plantas, seguido de más de 45 y hasta 55 mil plantas con el $25 \%$. De manera conjunta ambas densidades de siembra representaron más del $72 \%$. El porcentaje complementario se distribuyó en otras densidades. La menor densidad de siembra (hasta 35 mil plantas) se presenta en productores de nivel de adopción tecnológica baja, mientras que la mayoría de los productores de los niveles bajo y medio siembran de 35 y hasta 45 mil plantas, mientras que

Table 4. Technification of activities

Cuadro 4. Tecnificación de actividades

\begin{tabular}{|c|c|c|c|c|c|c|}
\hline \multirow[t]{2}{*}{ Component /Componente } & \multirow[t]{2}{*}{ Scale /Escala } & \multicolumn{5}{|c|}{ Technological level /Nivel tecnológico } \\
\hline & & $\begin{array}{c}\text { General } \\
(\%) / \\
\text { General } \\
(\%)\end{array}$ & $\begin{array}{c}\text { Very low } \\
(\%) / \\
\text { Muy bajo } \\
(\%)\end{array}$ & $\begin{array}{l}\text { Low (\%) / } \\
\text { Bajo (\%) }\end{array}$ & $\begin{array}{l}\text { Medium } \\
\text { (\%) / } \\
\text { Medio } \\
\text { (\%) }\end{array}$ & $\begin{array}{l}\text { High } \\
(\%) / \\
\text { Alto } \\
(\%)\end{array}$ \\
\hline \multirow{3}{*}{$\begin{array}{l}\text { Field preparation / } \\
\text { Preparación del terreno }\end{array}$} & Mechanical /Mecánica & 44.1 & 0.0 & 36.8 & 58.3 & 67.0 \\
\hline & Manually /Manual & 13.2 & 67.0 & 13.2 & 8.3 & 33.0 \\
\hline & Both / Ambas & 42.6 & 33.0 & 50.0 & 33.3 & 0.0 \\
\hline \multirow{3}{*}{$\begin{array}{l}\text { Fertilizer application / } \\
\text { Aplicación de fertilizantes }\end{array}$} & No fertilizer /No aplica & 4.4 & 100 & 0.0 & 0.0 & 0.0 \\
\hline & $\begin{array}{l}\text { Spraying backpack / } \\
\text { Mochila aspersora }\end{array}$ & 69.1 & 0.0 & 89.5 & 54.2 & 0.0 \\
\hline & $\begin{array}{l}\text { Mechanical sprinkler / } \\
\text { Aspersora mecánica }\end{array}$ & 26.5 & 0.0 & 10.5 & 45.8 & 100 \\
\hline \multirow{3}{*}{$\begin{array}{l}\text { Pesticide application / } \\
\text { Aplicación de plaguicidas }\end{array}$} & No pesticide /No aplica & 2.9 & 33.0 & 2.6 & 0.0 & 0.0 \\
\hline & Spraying backpack /Mochila aspersora & 73.5 & 67.0 & 79.0 & 75.0 & 0.0 \\
\hline & Mechanical sprinkler /Aspersora mecánica & 23.5 & 0.0 & 18.4 & 25.0 & 100 \\
\hline \multirow{3}{*}{$\begin{array}{l}\text { Application of ripening regulators / } \\
\text { Aplicación de reguladores de } \\
\text { maduración }\end{array}$} & No ripening regulators /No aplica & 26.5 & 67.0 & 36.8 & 8.3 & 0.0 \\
\hline & Spraying backpack /Mochila aspersora & 58.8 & 33.0 & 55.3 & 70.8 & 33.0 \\
\hline & Mechanical sprinkler /Aspersora mecánica & 14.7 & 0.0 & 7.9 & 20.8 & 67.0 \\
\hline \multirow[t]{5}{*}{ Weed control /Control de malezas } & Manually and shovel /Manual o tarpala & 14.7 & 0.0 & 23.7 & 4.2 & 0.0 \\
\hline & Manualy and spraying /backpack / & 32.4 & 100 & 18.4 & 45.8 & 0.0 \\
\hline & Manual y mochila aspersora & & & & & \\
\hline & Spraying backpack /Mochila aspersora & 42.6 & 0.0 & 55.3 & 33.3 & 33.0 \\
\hline & Mechanical /Mecánica & 10.3 & 0.0 & 2.6 & 16.7 & 67.0 \\
\hline \multirow[t]{4}{*}{ Floral induction /Inducción floral } & Manually /Manual & 8.8 & 0.0 & 13.2 & 4.2 & 0.0 \\
\hline & $\begin{array}{l}\text { Manually and spraying / backpack / } \\
\text { Manual y mochila aspersora }\end{array}$ & 22.1 & 67.0 & 26.3 & 12.5 & 0.0 \\
\hline & Spraying backpack /Mochila aspersora & 41.2 & 33.0 & 36.8 & 54.2 & 0.0 \\
\hline & Mechanical /Mecánica & 27.9 & 0.0 & 23.7 & 29.2 & 100 \\
\hline \multirow{4}{*}{$\begin{array}{l}\text { Fungicide application / } \\
\text { Aplicación de fungicidas }\end{array}$} & No application /No hace aplicaciones & 5.9 & 33.0 & 2.6 & 8.3 & 0.0 \\
\hline & Manually /Manual & 14.7 & 67.0 & 21.1 & 0.0 & 0.0 \\
\hline & Spraying backpack /Mochila aspersora & 61.8 & 0.0 & 71.1 & 62.5 & 0.0 \\
\hline & Mechanical /Mecánica & 17.6 & 0.0 & 5.3 & 29.2 & 100 \\
\hline
\end{tabular}


most use of mechanization to carry out these activities, in most cases, primarily at the very low, low and medium levels, the use of a spray backpack or the combination of manual applications with a spray backpack predominates (Table 4).

Despite the fact that agricultural mechanization is considered to increase labor productivity (Linck, 1985), the low percentages in the use of machinery and equipment to carry out land preparation and the application of agrochemicals in pineapple crops in Loma Bonita, Oaxaca, may be related to the economic problems involving particularly growers with very low and low level of technology adoption, the low financial capacity for the purchase of machinery and equipment, solve the constant increase in fuel prices and maintenance costs of tractors (Ayala, Audelo, \& Aragon, 2011). Therefore, for this type of growers, an alternative to carry out, above all, the activities of land preparation is to lease tractors and implements (Palacios \& Ocampo, 2012).

Raffia, newspaper, grasses, weeds or shade mesh can be used to cover the pineapple in this region. According to the analysis, the most used type of coverage is raffia with $55.9 \%$, tied to the tip of the plant's leaves which in turn cover the pineapple. Another $29.4 \%$ uses paper wrapping the fruit directly, only $14.7 \%$ mentioned to use shade mesh. It is distinguished that growers with high technological level have already changed to shadow mesh and only 16.7 of the medium level have adopted it completely. In the case of growers with a very low level of adoption, the use of newspaper stands out in $67 \%$ of cases, while growers with low level of adoption use raffia mostly (Table 5).

With regard to the new technologies incorporated into the pineapple production process since the last decade of the 20th century, such as plastic mulching, pressurized irrigation systems (sprinkling, microsprinkling and dripping), shade mesh and the MD2 variety, the low levels of adoption in all three cases stand out. As for mulching, $75 \%$ of the growers said they had not incorporated it into their crop and the rest ranging from less than $50 \%$ to $100 \%$. For pressurized irrigation systems, about $84 \%$ do not have this technology in any of its forms and only $4.4 \%$ have managed to incorporate it in all their land. Finally, for the shade mesh, more than $70 \%$ have not un porcentaje relevante del nivel alto llega a sembrar de 45 y hasta 55 mil plantas (Cuadro 3). En relación con esto, los productores con muy bajo y bajo nivel de adopción tecnológica al sembrar en superficies pequeñas con menor densidad de plantas por hectárea, así como la poca o nula incorporación de otras tecnologías que contribuyen a cosechar frutos de mejor calidad como malla sombra, acolchado y sistemas de riego, es muy probable que obtengan bajos rendimientos por hectárea, menor volumen de producción y poca calidad, por lo que al momento de la comercialización están en desventaja en la negociación de mejores precios ante los intermediarios, repercutiendo en menores ingresos, rentabilidad y capacidad de acceso a créditos, lo que dificulta a su vez la reinversión en la siembra de mayores superficies y la adquisición de nuevas tecnologías.

Para medir la tecnificación de las actividades que se realizan desde la preparación del terreno hasta que la fruta está lista para ser cosechada, se consideró el uso de maquinaria y equipo movidos mecánicamente, así como implementos y herramientas movidos a través de la fuerza física del hombre. En este caso, se destaca que la preparación del terreno que puede incluir actividades de chapeo, rastra, barbecho, nivelación, rayado, etc., se lleva a cabo en un $44.1 \%$ de los casos de forma

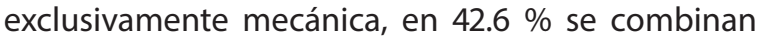
las actividades manuales y mecánicas y solo 13.2 $\%$ se realizan manualmente. Sobre esto, es posible apreciar que los niveles medio y alto son quienes realizan en mayor proporción dichas actividades de manera mecánica (Cuadro 4).

En el caso de aplicación líquida de diversos agroquímicos como fertilizantes, plaguicidas, reguladores de maduración, fungicidas, productos de inducción floral, como el control de malezas, son bajos los niveles de adopción de tecnología mecánica como el spray boom y la chapeadora, con rubros que no superan el $30 \%$, siendo los niveles medio y alto quienes más hacen uso de la mecanización para llevar a cabo estas actividades, en la mayoría de los casos, primordialmente en los niveles muy bajo, bajo y medio predomina el uso de mochila aspersora o la combinación de aplicaciones manuales con mochila aspersora (Cuadro 4). 
incorporated this technology, $17.6 \%$ have started to experiment with it and only a small part of about $10 \%$ have fully adopted it (Table 5 ).

Of the four technologies mentioned, the MD2 variety is the one that has been most adopted for low, medium and high levels, while the very low level continues sowing the cayena lisa variety, which may be an indication of what some producers comment that "the MD2 variety is more delicate and requires more care and therefore more investment, while the cayena lisa is a more rustic variety and endures more". In contrast, the least adopted technology is the irrigation system. This may be due to the high investment costs and licenses that must be incurred for implementation, with the highest percentages corresponding to the medium and high levels (Table 5).

It is worth mentioning that in the case of mulching, there are growers in the region with medium and high technological levels that have used this technology in their crop, but they are facing two problems, as: 1) greater proliferation of fungal diseases, due to excess moisture, which leads them to increase production costs by having to make a greater number of fungicide applications, and 2) what to do with mulching once its useful life ends, which also occurs with the shade mesh and the belt used in drip irrigation, and which could also explain the low levels of adoption of these technologies. Thus, although this type of new technology may require higher levels of investment, and as Pérez et al. (2016) point out that only a small part of farmers with financial capacity can adopt them, it is also true that there are certain environmental aspects, with economic consequences affecting the decision of growers to adopt them, so future studies should address these topics.

The use of agricultural machinery, especially in pre-sowing activities is important for the crop in order to develop maximum genetic potential (Rebolledo et al., 2011). In that sense, it is expected that growers with higher levels of technology carry out a greater number of activities to prepare their land, in order to obtain higher yields and better fruit quality. The results reflect that activities such as harrowing are carried out more than twice by $100 \%$ of growers at medium and high levels, and by more
A pesar de que se considera que la mecanización agrícola permite incrementar la productividad del trabajo (Linck, 1985), los bajos porcentajes en el uso de maquinaria y equipo para llevar a cabo la preparación del terreno y la aplicación de agroquímicos en el cultivo de la piña en Loma Bonita, Oaxaca, puede estar relacionado a los problemas económicos que implica particularmente para los productores con muy bajo y bajo nivel de adopción tecnológica, la poca capacidad financiera para la compra de maquinaria y equipo, solventar el incremento constante del precio de los combustibles y los costos de mantenimiento de los tractores (Ayala, Audelo, \& Aragón, 2011). Por lo que, para este tipo de productores, una alternativa para realizar, sobre todo, las actividades de preparación del terreno es la maquila o renta de tractor e implementos (Palacios \& Ocampo, 2012).

Para cubrir la piña en la región se puede utilizar rafia, papel periódico, pastos, malezas o malla sombra. De acuerdo con el análisis, el tipo de cobertura que se emplea en mayor medida es la rafia con el $55.9 \%$, con la cual se ata la punta de las hojas de la planta que a su vez cubren la piña. Otro $29.4 \%$ emplea papel con el cual se envuelve directamente el fruto, solo un $14.7 \%$ mencionó emplear malla sombra. Por estrato, se distingue que los productores con nivel tecnológico alto ya han hecho el cambio al uso de malla sombra y solo un 16.7 del nivel medio la an adoptado totalmente. En el caso de los productores con muy bajo nivel de adopción destaca el empleo de papel periódico en el $67 \%$ de los casos, mientras que los productores con nivel bajo emplean en su mayoría la rafia. (Cuadro 5).

En lo que se refiere a las nuevas tecnologías que se han estado incorporando al proceso de producción de piña desde la última década del siglo XX como el acolchado plástico, los sistemas de riego presurizado (aspersión, microaspersión y goteo), la malla sombra y la variedad MD2, sobresalen los bajos niveles de adopción en los tres casos. En cuanto al acolchado, el $75 \%$ de los productores manifestó no haberlo incorporado a su cultivo y el resto en rubros que van desde menos del $50 \%$ hasta el $100 \%$. Para los sistemas de riego presurizado, cerca del $84 \%$ no cuenta con esta tecnología en ninguna de sus modalidades y apenas el $4.4 \%$ ha 
Table 5. Method of coverage and new technologies for pineapple crops in the municipality of Loma Bonita, Oaxaca.

Tabla 5. Método de cobertura y nuevas tecnologías para el cultivo de piña en el municipio de Loma Bonita, Oaxaca.

\begin{tabular}{|c|c|c|c|c|c|c|}
\hline \multirow[t]{2}{*}{ Component/Componente } & \multirow[t]{2}{*}{ Scale/Escala } & \multicolumn{5}{|c|}{ Technological level / Nivel tecnológico } \\
\hline & & $\begin{array}{c}\text { General } \\
(\%) /\end{array}$ & $\begin{array}{c}\text { Very low } \\
(\%) / \\
\text { Muy bajo } \\
(\%)\end{array}$ & $\begin{array}{c}\text { Low } \\
\text { (\%)/ } \\
\text { Bajo } \\
(\%)\end{array}$ & $\begin{array}{c}\text { Medium } \\
\text { (\%)/ } \\
\text { Medio } \\
\text { (\%) }\end{array}$ & $\begin{array}{l}\text { High } \\
\text { (\%)/ } \\
\text { Alto } \\
\text { (\%) }\end{array}$ \\
\hline \multirow{4}{*}{$\begin{array}{l}\text { Coverage method/ } \\
\text { Método de cobertura }\end{array}$} & Grasses and weeds/Pastos o malezas & 0.0 & 0.0 & 0.0 & 0.0 & 0.0 \\
\hline & Newspaper/Periódico & 29.4 & 67.0 & 21.1 & 41.7 & 0.0 \\
\hline & Raffia/Rafia & 55.9 & 33.0 & 71.1 & 41.7 & 0.0 \\
\hline & Shadow mesh/Malla sombra & 14.7 & 0.0 & 7.9 & 16.7 & 100 \\
\hline \multirow{5}{*}{$\begin{array}{l}\text { Mulching / } \\
\text { Acolchado }\end{array}$} & Zero/Nada & 75.0 & 100 & 89.5 & 58.3 & 0.0 \\
\hline & Less than $50 \% /$ Menos del $50 \%$ & 8.8 & 0.0 & 7.9 & 12.5 & 0.0 \\
\hline & $50 \%$ & 1.5 & 0.0 & 2.6 & 0.0 & 0.0 \\
\hline & More than 50\% / Más del $50 \%$ & 7.4 & 0.0 & 0.0 & 8.3 & 100 \\
\hline & $100 \%$ & 7.4 & 0.0 & 0.0 & 20.8 & 0.0 \\
\hline \multirow{5}{*}{$\begin{array}{l}\text { Irrigation system / } \\
\text { Sistema de riego }\end{array}$} & Zero/Nada & 83.8 & 100 & 94.7 & 70.8 & 33.3 \\
\hline & Less than 50\% /Menos del $50 \%$ & 4.4 & 0.0 & 2.6 & 4.2 & 33.3 \\
\hline & $50 \%$ & 2.9 & 0.0 & 2.6 & 0.0 & 33.3 \\
\hline & More than 50\%Más del $50 \%$ & 4.4 & 0.0 & 0.0 & 12.5 & 0.0 \\
\hline & $100 \%$ & 4.4 & 0.0 & 0.0 & 12.5 & 0.0 \\
\hline \multirow{5}{*}{$\begin{array}{l}\text { Shadow mesh / } \\
\text { Malla sombra }\end{array}$} & Zero/Nada & 72.1 & 100 & 79.0 & 66.7 & 0.0 \\
\hline & Less than 50\% /Menos del $50 \%$ & 13.2 & 0.0 & 18.4 & 8.3 & 0.0 \\
\hline & $50 \%$ & 2.9 & 0.0 & 2.6 & 4.2 & 0.0 \\
\hline & More than 50\%/Más del $50 \%$ & 1.5 & 0.0 & 0.0 & 4.2 & 0.0 \\
\hline & $100 \%$ & 10.3 & 0.0 & 0.0 & 16.7 & 100 \\
\hline \multirow{6}{*}{$\begin{array}{l}\text { Area with MD2 / } \\
\text { Superficie con MD2 }\end{array}$} & $0 \%$ & 22.1 & 100 & 31.6 & 0.0 & 0.0 \\
\hline & $<20 \%$ & 30.9 & 0.0 & 44.7 & 16.7 & 0.0 \\
\hline & $>20$ but $\leq 40 \% />20$ pero $\leq 40 \%$ & 14.7 & 0.0 & 10.5 & 20.8 & 33.0 \\
\hline & $>40$ but $\leq 60 \% />40$ pero $\leq 60 \%$ & 16.2 & 0.0 & 5.3 & 29.2 & 67.0 \\
\hline & $>60$ but $\leq 80 \% />60$ pero $\leq 80 \%$ & 4.4 & 0.0 & 0.0 & 12.5 & 0.0 \\
\hline & $>80 \%$ & 11.8 & 0.0 & 7.9 & 20.8 & 0.0 \\
\hline
\end{tabular}

Source: Compiled by the author./Fuente: Elaboración propia

than $71 \%$ at the low level, representing the activity that is implemented more than twice overall. A significant percentage of growers with medium and high levels practice chapeo, fallowing, root lodging and furrowing at least twice. In contrast, growers with very low technological levels generally carry out these activities only once (Table 6).

With regard to the availability of agricultural machinery and equipment, the results show that the grower can own his tractor and equipment or lease it. A total of $47.1 \%$ of respondents said they have their own tractor and $44.1 \%$ said they lease it. A total logrado incorporarla en la totalidad de su terreno. Finalmente, para la malla sombra más del $70 \%$ no ha incorporado esta tecnología, $17.6 \%$ ha comenzado a experimentar con ella y solo una pequeña parte de alrededor del $10 \%$ la ha adoptado plenamente (Cuadro 5).

De las cuatro tecnologías mencionadas, se aprecia que la variedad MD2 es la que más se ha adoptado por los niveles bajo, medio y alto, mientras que el nivel muy bajo continúa con la siembra de la variedad cayena lisa, lo cual puede ser un indicativo de lo que comentan algunos productores en el 
Table 6. Amount of mechanical activities for the preparation of the land.

Tabla 6. Cantidad de actividades mecánicas para la preparación del terreno.

\begin{tabular}{|c|c|c|c|c|c|c|}
\hline \multirow{2}{*}{$\begin{array}{l}\text { Component/ } \\
\text { Componente }\end{array}$} & \multirow{2}{*}{$\begin{array}{l}\text { Scale / } \\
\text { Escala }\end{array}$} & \multicolumn{5}{|c|}{ Technological level/Nivel tecnológico } \\
\hline & & General (\%) / & $\begin{array}{l}\text { Very low (\%) / } \\
\text { Muy bajo (\%) }\end{array}$ & $\begin{array}{l}\text { Low (\%) / } \\
\text { Bajo (\%) }\end{array}$ & $\begin{array}{l}\text { Medium (\%) / } \\
\text { Medio (\%) }\end{array}$ & $\begin{array}{c}\text { High (\%) / } \\
\text { Alto (\%) }\end{array}$ \\
\hline \multirow[t]{3}{*}{ Chapeo } & OneNno & 14.7 & 100.0 & 13.2 & 5.3 & 0.0 \\
\hline & Two/Dos & 52.9 & 0.0 & 65.8 & 23.7 & 33.0 \\
\hline & More than 2 /Más de 2 & 32.4 & 0.0 & 21.1 & 34.2 & 67.0 \\
\hline \multirow{3}{*}{$\begin{array}{l}\text { Subsoiling/ } \\
\text { Subsoleo }\end{array}$} & One/Uno & 27.9 & 100.0 & 21.1 & 20.8 & 100.0 \\
\hline & Two/Dos & 51.5 & 0.0 & 63.2 & 45.8 & 0.0 \\
\hline & More than 2/Más de 2 & 20.6 & 0.0 & 15.8 & 33.3 & 0.0 \\
\hline \multirow{3}{*}{$\begin{array}{l}\text { Fallowing/ } \\
\text { Barbecho }\end{array}$} & One/Uno & 27.9 & 100.0 & 34.2 & 12.5 & 0.0 \\
\hline & Two/Dos & 42.6 & 0.0 & 47.4 & 33.3 & 100.0 \\
\hline & More than 2/Más de 2 & 29.5 & 0.0 & 18.4 & 54.2 & 0.0 \\
\hline \multirow{3}{*}{$\begin{array}{l}\text { Harrowing/ } \\
\text { Rastreo }\end{array}$} & One/Uno & 2.9 & 67.0 & 0.0 & 0.0 & 0.0 \\
\hline & Two/Dos & 16.2 & 0.0 & 29.0 & 0.0 & 0.0 \\
\hline & More than 2/Más de 2 & 80.9 & 33.0 & 71.1 & 100.0 & 100.0 \\
\hline \multirow{3}{*}{$\begin{array}{l}\text { Lodging/ } \\
\text { Acame }\end{array}$} & One/Uno & 54.4 & 100.0 & 63.2 & 41.7 & 0.0 \\
\hline & Two/Dos & 32.4 & 0.0 & 29.0 & 37.5 & 67.0 \\
\hline & More than 2/Más de 2 & 13.2 & 0.0 & 7.9 & 20.8 & 33.0 \\
\hline \multirow{3}{*}{$\begin{array}{l}\text { Furrowing/ } \\
\text { Rayado }\end{array}$} & One/Uno & 10.3 & 67.0 & 10.5 & 4.2 & 0.0 \\
\hline & Two/Dos & 69.1 & 33.0 & 79.0 & 54.2 & 100.0 \\
\hline & More than 2/Más de 2 & 20.6 & 0.0 & 10.5 & 41.7 & 0.0 \\
\hline
\end{tabular}

Source: Compiled by the author / Fuente: Elaboración propia

of $47.1 \%$ has its own mower and $44.1 \%$ leases it; $35.3 \%$ has a disc plow and $30.9 \%$ leases it; $42.6 \%$ has a harrow and $45.6 \%$ leases it. High percentages of growers do not use technologies such as moldboard plow, drainage equipment, leveler, bed shaper and spray booms, although there are significant percentages of growers that can rent chisel plows or bed shapers, or they own spray booms and chisel plows (Table 7).

An analysis by technology level reveals that medium and high level are those that for the most part have a tractor and some implements like mowers, disc plow, harrow and spray boom. Low level growers usually have to lease a tractor, mower, harrow and chisel plow, while growers with very low technological level do not use this type of equipment, and if needed, they lease them. In this sense, high cost of investment is relevant, as well as the size of the area they cultivate, which represents an impediment for small growers to have their own equipment.

The high demand for agrochemicals during almost the entire production cycle of pineapple is sentido de que "la variedad MD2 es más delicada y requiere de mayores cuidados $y$, por ende, de mayor inversión, mientras que la cayena lisa es una variedad más rústica y aguanta más". Por el contrario, la tecnología menos adoptada es el sistema de riego. Esto se puede deber a los altos costos de inversión y permisos que se deben realizar para su implantación, correspondiendo los mayores porcentajes a los niveles medio y alto (Cuadro 5).

Cabe mencionar que en el caso del acolchado, existen productores de la región con niveles tecnológicos medio y alto que han incorporado esta tecnología en su cultivo, pero que están enfrentando dos problemas, como son: 1) mayor proliferación de enfermedades de tipo fungoso, por el exceso de humedad, lo que los lleva a incrementar los costos de producción al tener que hacer mayor número de aplicación de fungicidas, y 2) qué hacer con el acolchado una vez que termina su vida útil, lo cual también ocurre con la malla sombra y la cintilla usada en el riego por goteo, y que podrían también explicar los bajos niveles de adopción de estas 
evident, since, of the total members of the sample collected, $54.4 \%$ carry out 1 to 3 applications of pesticides, followed by those who carry out 4 to 6 applications with $32.4 \%$, together representing about $87 \%$. Similarly, the percentages for the corresponding herbicides for the options of 1 to 3 and 4 to 6 applications, respectively, were 70.6 and $20.6 \%$, which together constitute more than $90 \%$. While, for fungicides, the percentages in the same order reached 51.5 and $30.9 \%$, which cumulatively are above $82 \%$.

It also shows the importance of fertilizer application at different stages of cultivation. Thus, $45.6 \%$ of growers carry out 4 to 6 applications and $42.6 \%$ more than 6 . Unlike fertilizers, the application of products for the floral induction of pineapple and ripening accelerators are used in less proportion. In this sense, $80 \%$ of the pineapple growers carry out 1 to 3 times the floral induction treatment. For the same amount of applications, 58.8\% apply ripening accelerators and, a little more than a quarter of the interviewees do not apply this type of product.

The above results coincide with those reported by Damián et al. (2007), who deduced that the higher the level of technological appropriation of the growers, the greater the use of technology that includes the use of a tractor for fallowing activities, harrowing, furrowing, sowing improved seed and application of herbicides, fertilizers and insecticides.

\section{Conclusions}

This study allowed the classification of four types of production units according to the level of technological adoption (very low, low, medium and high), which showed that few pineapple growers in the municipality of Loma Bonita, Oaxaca have or have been able to adopt expensive technologies systems in their production units such as tractors, agricultural implements, shade mesh, mulching, and pressurized irrigation, sowing the MD2 variety, contracting services such as soil and water analysis and technical advice, either because of limitations in surface area, economic resources, or perhaps because each stratum adopts innovations according to form of production, causing a low percentage of growers with high levels of adoption, contrasting with the large percentage of those with low levels of technological adoption. tecnologías. De tal manera que, si bien este tipo de nuevas tecnologías pueden requerir mayores niveles de inversión, y como lo señalan Pérez et al. (2016) que solo una pequeña parte de los agricultores con capacidad financiera pueden adoptarlas, también es cierto, que existen ciertos aspectos de tipo ambiental, con consecuencias económicas que afectan la decisión de adopción de los productores, por lo que futuros estudios deberán abordar estos tópicos.

El uso de la maquinaria agrícola, sobre todo, en las actividades previas a la siembra, es de suma importancia para que el cultivo desarrolle su máximo potencial genético (Rebolledo et al., 2011). En ese sentido, se espera que los productores con mayores niveles tecnológicos realicen un mayor número de actividades para preparar su terreno, con el propósito de obtener mayores rendimientos y mejor calidad del fruto. Los resultados reflejan que actividades como el rastreo se llevan a cabo más de dos veces por el $100 \%$ de los productores de los niveles medio y alto, y por más del $71 \%$ del nivel bajo, representando la actividad que se ejecuta más de dos veces de manera general. Porcentaje importante de productores de los niveles medio y alto, practican por lo menos dos veces el chapeo, barbecho, acame y rayado. Por el contrario, los productores con muy bajo nivel tecnológico realizan dichas actividades generalmente una sola vez (Cuadro 6).

Con respecto a la disponibilidad de maquinaria y equipo agrícola, los resultados muestran que el productor puede ser propietario de su tractor $y$ equipo o en su defecto rentarlo. En el caso del tractor, el $47.1 \%$ de los encuestados manifestó contar con su propia unidad y $44.1 \%$ indicó rentarlo. En cuanto a la chapeadora, el $47.1 \%$ cuenta con su propio equipo y $44.1 \%$ lo renta; $35.3 \%$ dispone de arado de discos y $30.9 \%$ lo renta; $42.6 \%$ cuenta con rastra y $45.6 \%$ la renta. Elevados porcentajes de productores no utilizan tecnologías como el arado de reja, equipo para la construcción de drenes, niveladora, acamadora y spray boom, aunque hay porcentajes significativos de productores que pueden rentar el arado de cinceles o la acamadora, o en su defecto son propietarios de spray boom y arado de cinceles (Cuadro 7).

Un análisis por nivel tecnológico revela que son los niveles medio y alto los que cuentan en su 
Table7. Availability of agricultural machinery of pineapple growers. Cuadro 7. Disponibilidad de maquinaria agrícola de los productores de piña.

\begin{tabular}{|c|c|c|c|c|c|c|}
\hline \multirow[t]{2}{*}{ Component/Componente } & \multirow[t]{2}{*}{ Scale/Escala } & \multicolumn{5}{|c|}{ Technological level/Nivel tecnológico } \\
\hline & & General (\%) & $\begin{array}{c}\text { Very low } \\
(\%) / \\
\text { Muy bajo } \\
(\%)\end{array}$ & $\begin{array}{l}\text { Low (\%)/ } \\
\text { Bajo (\%) }\end{array}$ & $\begin{array}{c}\text { Medium } \\
(\%) / \\
\text { Medio (\%) }\end{array}$ & $\begin{array}{l}\text { High (\%) } \\
\text { Alto (\%) }\end{array}$ \\
\hline \multirow[t]{4}{*}{ Tractor } & Don't use/No utiliza & 4.4 & 67.0 & 2.6 & 0.0 & 0.0 \\
\hline & Borrowed/Prestado & 4.4 & 0.0 & 7.9 & 0.0 & 0.0 \\
\hline & Leased/Arrendado & 44.1 & 33.0 & 57.9 & 29.2 & 0.0 \\
\hline & Own/Propio & 47.1 & 0.0 & 31.6 & 70.8 & 100 \\
\hline \multirow[t]{4}{*}{ Mower/Chapeadora } & Don't use/No utiliza & 13.2 & 100 & 15.8 & 0.0 & 0.0 \\
\hline & Borrowed/Prestado & 1.5 & 0.0 & 2.6 & 0.0 & 0.0 \\
\hline & Leased/Arrendado & 41.2 & 0.0 & 55.3 & 29.2 & 0.0 \\
\hline & Own/Propio & 44.1 & 0.0 & 26.3 & 70.8 & 100 \\
\hline \multirow[t]{4}{*}{ Moldboard plow/Arado de reja } & Don't use/No utiliza & 60.3 & 100 & 76.3 & 29.2 & 67.0 \\
\hline & Borrowed/Prestado & 1.5 & 0.0 & 2.6 & 0.0 & 0.0 \\
\hline & Leased/Arrendado & 17.6 & 0.0 & 13.2 & 29.2 & 0.0 \\
\hline & Own/Propio & 20.6 & 0.0 & 7.9 & 41.7 & 33.0 \\
\hline \multirow[t]{4}{*}{ Disc plow/Arado de discos } & Don't use/No utiliza & 32.4 & 100 & 39.5 & 16.7 & 0.0 \\
\hline & Borrowed/Prestado & 1.5 & 0.0 & 2.6 & 0.0 & 0.0 \\
\hline & Leased/Arrendado & 30.9 & 0.0 & 39.5 & 25.0 & 0.0 \\
\hline & Own/Propio & 35.3 & 0.0 & 18.4 & 58.3 & 100 \\
\hline \multirow[t]{4}{*}{ Harrow/Rastra } & Don't use/No utiliza & 8.8 & 67.0 & 10.5 & 0.0 & 0.0 \\
\hline & Borrowed/Prestado & 2.9 & 0.0 & 5.3 & 0.0 & 0.0 \\
\hline & Leased/Arrendado & 45.6 & 33.0 & 57.9 & 33.3 & 0.0 \\
\hline & Own/Propio & 42.6 & 0.0 & 26.3 & 66.7 & 100 \\
\hline \multirow[t]{4}{*}{ Chisel plow/Arado de cinceles } & Don't use/No utiliza & 44.1 & 100 & 44.7 & 41.7 & 0.0 \\
\hline & Borrowed/Prestado & 4.4 & 0.0 & 5.3 & 4.2 & 0.0 \\
\hline & Leased/Arrendado & 30.9 & 0.0 & 42.1 & 20.8 & 0.0 \\
\hline & Own/Propio & 20.6 & 0.0 & 7.9 & 33.3 & 100 \\
\hline \multirow{4}{*}{$\begin{array}{l}\text { Drain construction equipment/ } \\
\text { Equipo para construcción de drenes }\end{array}$} & Don't use/No utiliza & 72.1 & 100 & 86.8 & 54.2 & 0.0 \\
\hline & Borrowed/Prestado & 0.0 & 0.0 & 0.0 & 0.0 & 0.0 \\
\hline & Leased/Arrendado & 14.7 & 0.0 & 10.5 & 25.0 & 0.0 \\
\hline & Own/Propio & 13.2 & 0.0 & 2.6 & 20.8 & 100 \\
\hline \multirow[t]{4}{*}{ Leveler/Niveladora } & Don't use/No utiliza & 73.5 & 100 & 86.8 & 54.2 & 33.0 \\
\hline & Borrowed/Prestado & 1.5 & 0.0 & 2.6 & 0.0 & 0.0 \\
\hline & Leased/Arrendado & 17.6 & 0.0 & 7.9 & 37.5 & 0.0 \\
\hline & Own/Propio & 7.4 & 0.0 & 2.6 & 8.3 & 67.0 \\
\hline \multirow[t]{4}{*}{ Bed shaper/Acamadora } & Don't use/No utiliza & 63.2 & 100 & 78.9 & 41.7 & 0.0 \\
\hline & Borrowed/Prestado & 0.0 & 0.0 & 0.0 & 0.0 & 0.0 \\
\hline & Leased/Arrendado & 26.5 & 0.0 & 18.4 & 45.8 & 0.0 \\
\hline & Own/Propio & 10.3 & 0.0 & 2.6 & 12.5 & 100 \\
\hline \multirow[t]{4}{*}{ Spray boom/Spray boom } & Don't use/No utiliza & 60.3 & 100 & 78.9 & 33.3 & 0.0 \\
\hline & Borrowed/Prestado & 2.9 & 0.0 & 5.3 & 0.0 & 0.0 \\
\hline & Leased/Arrendado & 14.7 & 0.0 & 7.9 & 29.2 & 0.0 \\
\hline & Own/Propio & 22.1 & 0.0 & 7.9 & 37.5 & 100 \\
\hline
\end{tabular}

Source: Compiled by the author/Fuente: Elaboración propia.

Although it is inferred that the size of the planted area is important to achieve higher levels of technology adoption, financial capacity is a key element to have highly technical production units, because, in addition to the technologies mentioned, mayoría con tractor y algunos implementos como chapeadora, arado de discos, rastra y spray boom. En el caso del nivel bajo por lo regular deben rentar el tractor, chapeadora, rastra y arado de cinceles, mientras que para los productores de muy bajo 
pineapple crop depends largely on agrochemicals such as fertilizers, pesticides, herbicides, fungicides, among others, which have the particularity of increasing the cost in greater proportion to the selling price of the fruit.

On the other hand, given the low production volumes and low quality of pineapple obtained by growers with very low adoption levels, their negotiating power vis-à-vis intermediaries is limited, affecting their income, profitability and ability to access sources of financing, affecting reinvestment in the sowing of larger areas and the acquisition of other technologies. Therefore, in the future, support policies focused on agricultural activity and particularly on pineapple crops, should be based on the development of competitive capacities of growers, technical assistance in both productive and economic-administrative issues (market trends, quality improvement, product differentiation, organization, among others), as well as financing, which will allow to enhance such capacities to motivate them to access and serve new markets, to increase the level of technology on the basis of the economic and productive limitations that characterize above all those who have production units with a very low, low and medium level of technology, but who wish to overcome these technological thresholds. Therefore, it is necessary to take into account socioeconomic characteristics such as age and level of education, which are important since they are positively related to the ability to learn.

A recommendation that emerges from this study and should be considered for future research is to identify those factors, personal, social, cultural, economic, among others, that are positively related to different levels of technological adoption in the production of pineapple, not only for the municipality of Loma Bonita, Oaxaca, but also for those municipalities in different states of Mexico where this crop is important from an economic and social point of view, since it is considered that there is a long list of factors that can influence the decision of adoption by growers.

Another alternative to improve the conditions in the commercialization of pineapple for growers with very low, low and medium levels of technological adoption, is to integrate into the pineapple value nivel tecnológico es común no emplear este tipo de equipos, y de hacerlo, tienen que recurrir a la renta de estos. En este sentido, toma relevancia el alto costo de inversión, así como el tamaño de superficie que cultivan, que representa un impedimento para que los pequeños productores puedan contar con sus propios equipos.

La alta demanda de agroquímicos durante prácticamente todo el ciclo de producción de la piña queda de manifiesto, ya que, del total de los integrantes de la muestra recabada, el $54.4 \%$ lleva a cabo de 1 a 3 aplicaciones de plaguicidas, seguido de aquellos que realizan de 4 a 6 con el $32.4 \%$; de manera conjunta representan alrededor del $87 \%$. En el mismo sentido, los porcentajes para los herbicidas correspondientes para las opciones de 1 a 3 y de 4 a 6 aplicaciones, en forma respectiva, fueron de 70.6 y $20.6 \%$ que en suma constituyen más del $90 \%$. Mientras que, para los fungicidas, los porcentajes en el mismo orden alcanzaron 51.5 y $30.9 \%$, cuyo acumulado está por encima del $82 \%$.

También queda de manifiesto la importancia de la aplicación de fertilizantes en las diferentes etapas del cultivo. Así, el $45.6 \%$ de los productores efectúan de 4 a 6 aplicaciones y el $42.6 \%$ más de 6. A diferencia de los fertilizantes, la aplicación de productos para la inducción floral de la piña y aceleradores de maduración son utilizados en menor proporción. En este sentido, $80 \%$ de los piñeros hace de 1 a 3 veces el tratamiento de inducción floral. Para la misma cantidad de aplicaciones un $58.8 \%$ aplica aceleradores de maduración y, poco más de un cuarto de los entrevistados no aplica este tipo de productos.

Los resultados anteriores coinciden con lo reportado por Damián et al. (2007), quienes dedujeron que, a mayor nivel de apropiación tecnológica de los productores, se hace un mayor uso de tecnología que incluye el empleo del tractor para actividades de barbecho, rastreo, surcado, siembra de semilla mejorada y aplicación de herbicidas, fertilizantes e insecticidas.

\section{Conclusiones}

Este trabajo permitió clasificar cuatro tipos de unidades de producción de acuerdo al nivel de adopción tecnológica (muy bajo, bajo, medio y alto), 
chain, which allows them to access information on new global consumption trends, such as the emergence of niche markets that demand safe and sustainable products, i.e., that care for health and in their production process cause the least damage to the environment, so they are willing to pay higher prices than those paid for fruit grown intensively. This requires that government agencies, intermediaries and other actors related to pineapple crops provide data on where these niches are located, what the requirements are to access them, among others.

Finally, although the present study represents a first approach to know the conditions in which the production of so important crop for the region of Papaloapan is carried out, it is necessary to consider that there are orientation of the production and regional factors of each area of study, reason why future studies applied in the region, will have to consider not only socioeconomic and technological factors like those approached in this study, but also others that according to the literature influence in a negative or positive way the decision to adopt technologies, such as the exposure of growers to different media, access to subsidies and credits, market demands, insecurity, among others, and that allow a more accurate judgment on the factors that determine the technological heterogeneity of the pineapple production units at local, municipal and regional level.

End of English version

\section{References/Referencias}

Aguilar G., N., Muñoz, M., Santoyo, V., \& Aguilar, J. (2013). "Influencia del perfil de los productores en la adopción de innovaciones en tres cultivos tropicales". Teuken Bidikay (4):207-228.

Arribas, M. (2004). "Diseño y validación de cuestionarios". Matronas Profesión 5 (17):23-29.

Ávila J., A. (2001). "El mercado de los fertilizantes en México/Situación actual y perspectivas". Problemas del Desarrollo 32 (127):189-207.

Ayala, G., A. V., Audelo, M., \& Aragón, A. (2011). “La situación del mercado de tractores en México, con lo que se pudo constatar que pocos productores de piña del municipio de Loma Bonita, Oaxaca cuentan o han podido adoptar e incorporar a sus unidades de producción, tecnologías costosas como el tractor, implementos agrícolas, malla sombra, acolchado, sistemas de riego presurizado, siembra de la variedad MD2, la contratación de servicios como análisis de suelo, agua y asesoría técnica, ya sea por limitantes de superficie, recursos económicos, o quizás porque cada estrato adopta innovaciones acordes a su forma de producción, provocando que exista un bajo porcentaje de agricultores con niveles altos de adopción, que contrasta con el amplio porcentaje de aquellos con niveles bajos de adopción tecnológica.

Aunque se infiere que el tamaño de la superficie sembrada es importante para lograr mayores niveles de adopción tecnológica, la capacidad financiera es un elemento clave para contar con unidades de producción altamente tecnificadas, ya que, además de las tecnologías mencionadas, el cultivo de la piña depende ampliamente de agroquímicos como fertilizantes, plaguicidas, herbicidas, fungicidas, entre otros, los cuales tienen la particularidad de incrementar el costo en mayor proporción al precio de venta de la fruta.

Por otro lado, ante los bajos volúmenes de producción y la baja calidad de la piña que obtienen los productores de niveles de adopción muy bajo y bajo, su poder de negociación frente a los intermediarios se ve limitado, afectando sus ingresos, rentabilidad y capacidad de acceder a fuentes de financiamiento, lo que dificulta la reinversión en la siembra de mayores superficies y la adquisición de otras tecnologías. Por lo que, en el futuro, las políticas de apoyo enfocadas a la actividad agrícola y particularmente para el cultivo de la piña, deberán basarse en el desarrollo de capacidades competitivas de los productores, asistencia técnica en temas tanto productivos como económicos-administrativos (tendencias de mercado, mejoramiento de la calidad, diferenciación de productos, organización, entre otros), así como de financiamiento, que permitan potencializar dichas capacidades, para motivarlos a acceder y atender a nuevos mercados, buscando con esto incrementar el nivel tecnológico a partir de las limitantes económicas y productivas que 
perspectivas y retos en la certificación". Textual Análisis del Medio Rural Latinoamericano (58):91111.

Borja B., M., Vélez, A., \& Ramos, J. (2018). "Tipología y diferenciación de productores de guayaba (Psidiumguajava I.) en Calvillo, Aguascalientes, México". Región y Sociedad 3 (71):1-22.

Cáceres D., Silvetti, F., Soto, G., \& Rebolledo, W. (1997). "La adopción tecnológica en sistemas agropecuarios de pequeños productores". Agro Sur 25 (2):1-15.

Chalate M., H., Gallardo, F., Pérez, P., Lang, F., Ortega, E., \& Vilaboa, J. (2010). “Características del sistema de producción bovinos de doble propósito en el estado de Morelos, México". Zootecnia Tropical 28 (3):329-339.

Cih-Dzul I., R., Jaramillo, J., Tornero, A., \& Schwentesius, R. (2011). "Caracterización de los sistemas de producción de tomate (Lycopersicum esculentum Mill.) en el Estado de Jalisco, México". Tropical and Subtropical Agroecosystems 14 (2):501-512.

CIMMYT. (1993). "La adopción de tecnologías agrícolas: Guía para el diseño de encuestas". CIMMYT. Distrito Federal, México. 88 p.

Cuevas R., V., Baca, J., Cervantes, F., Espinosa, J., Aguilar, J., \& Loaiza, A. (2013). "Factores que determinan el uso de innovaciones tecnológicas en la ganadería de doble propósito en Sinaloa, México". Revista Mexicana de Ciencias Pecuarias 4 (1):31-46.

Cuevas R., V., Loaiza, A., Espinosa, J., Vélez, A., \& Montoya, M. (2016). "Tipología de las explotaciones ganaderas de bovinos de doble propósito en Sinaloa, México". Revista Mexicana de Ciencias Pecuarias 7 (1):69-83.

Damián H., M. A., Ramírez, B., Parra, F., Paredes, J., Gil, A.,.., López, J. (2007). "Apropiación de tecnología por productores de maíz en el estado de Tlaxcala, México". Agricultura Técnica de México 33 (2):163173.

Duch G., J. (1998). “Tipologías empíricas de productores agrícolas y tipos ideales en el estudio de la agricultura regional". Revista de Geografía Agrícola (27):27-38.

Dufumier, M. (1990). "Importancia de la tipología de unidades de producción agrícolas en el caracterizan sobre todo, a aquellos que cuentan con unidades de producción con nivel tecnológico muy bajo, bajo y medio, pero con deseos de superar estos umbrales tecnológicos, por lo que es necesario tomar en cuenta características socioeconómicas como la edad y el nivel escolar, trascendentales toda vez que se les relaciona positivamente con la capacidad de aprendizaje.

Una recomendación que se desprende de este trabajo y que se deberá considerar para futuras investigaciones, es el de identificar aquellos factores tanto personales, sociales, culturales, económicos, entre otros, que se relacionan positivamente con los diferentes niveles de adopción tecnológica en la producción de piña, no solo para el municipio de Loma Bonita, Oaxaca, sino también para aquellos municipios de las diferentes entidades federativas de México donde su cultivo es importante tanto desde el punto de vista económico como social, ya que se considera existe una larga lista de factores que pueden influir en la decisión de adopción por parte de los productores.

Otra alternativa para mejorar las condiciones en la comercialización de la piña para los productores de niveles de adopción tecnológica muy bajo, bajo y medio, es integrarse a la cadena de valor piña, que les permita acceder a información sobre las nuevas tendencias mundiales de consumo, como el surgimiento de nichos de mercados que demandan productos inocuos y sustentables, es decir, que cuiden la salud y que en su proceso de producción causen el menor daño al medio ambiente, por lo que están dispuestos a pagar precios superiores a los pagados por frutos cultivados de manera intensiva. Para ello, se requiere que organismos gubernamentales, intermediarios y demás actores relacionados con el cultivo de piña proporcionen datos relativos de dónde se encuentran estos nichos, cuáles son los requisitos para acceder a ellos, entre otros.

Finalmente, aunque este trabajo representa un primer acercamiento para conocer las condiciones en las cuales se lleva a cabo la producción de tan importante cultivo para la región del Papaloapan, es necesario tener presente que existen factores regionales y de orientación de la producción propios de cada zona de estudio, por lo que estudios futuros aplicados en la región, deberán considerar no solo 
análisis diagnóstico de realidades agrarias". En: Tipificación de sistemas de producción agrícola. Escobar, G y J. Berdegué (Editores) Santiago de Chile. pp. 63-81.

Escobar, G., \& Berdegué, J. (1990). "Conceptos y metodología para la tipificación de sistemas de finca: La experiencia de RIMISP". En: Tipificación de sistemas de producción agrícola. Escobar, $\mathrm{G}$ y J. Berdegué (Editores) Santiago de Chile. pp. 13-43. SAGARPA-FAO. (2012). Diagnóstico del sector rural y pesquero de México 2012. Secretaría de Agricultura, Ganadería, Desarrollo Rural, Pesca y Alimentación-Organización de las Naciones Unidas para la Alimentación y la Agricultura. 68 p.

FAOSTAT. (2018). Food and Agriculture Organization of the United Nations. (Publicación en línea, disponible en internet en el sitio http://www. fao.org/faostat/es/\#data/QC [con acceso el 15-82018])

Galindo G., G., Tabares, W., \& Gómez, G. (2000). "Caracterización de productores de seis distritos de desarrollo rural de Zacatecas". Terra 18 (1):83-92.

García S., E. I.; Aguilar, J., \& Bernal, R. (2011). "La agricultura protegida de Tlaxcala, Méjico: la adopción de innovaciones y el nivel de equipamiento como factores para su categorización". Teuken Bidikay (1):193-212.

Gil M., J., \& Vivar, J. (2015). “La modernización agrícola en México y sus repercusiones en espacios rurales". Revista Antropologías del Sur (3):51-67.

Hernández M., P., Estrada, J., Avilés, F., Yong, G., López, F.,..., Castelán, O. (2013). "Tipificación de los sistemas campesinos producción de leche del sur del Estado de México". Universidad y Ciencia Trópico Húmedo 29 (1):19-31.

Hernández S., R., Fernández, C., \& Baptista, M. (2010). "Metodología de la investigación". McGraw-Hill/ Interamericana Editores, S.A. de C.V. Distrito Federal, México. $613 \mathrm{p}$.

Hernández T., J. M., \& Barrón, M. (2013). "Las empresas agrícolas mexicanas y sus sistemas de aprovisionamiento de trabajadores". Sociología 28 (80):209-240.

INEGI. (2005). Cuaderno Estadístico Municipal: Loma Bonita, Oaxaca. Edición (2005). Aguascalientes, México. $170 \mathrm{p}$.

Kleeberg H., F., \& Ramos, J. (2009). "Aplicación de factores socioeconómicos y tecnológicos como los abordados en esta investigación, sino también otros que de acuerdo con la literatura influyen en forma negativa o positiva en la decisión de adopción de tecnologías como lo son la exposición de los productores a diversos medios de comunicación, acceso a subsidios y créditos, exigencias del mercado, inseguridad, entre otros, y que permitan emitir un juicio más preciso sobre los factores que determinan la heterogeneidad tecnológica de las unidades de producción de la piña tanto a nivel local, municipal y regional.

Fin de la versión en español

las técnicas de muestreo en los negocios y la industria". Ingeniería Industrial (27):11-40.

Leos R., J. A., Serrano, A., Salas, J., Ramírez, P., \& Sagarnaga, M. (2008). "Caracterización de ganaderos y unidades de producción pecuaria beneficiarios del programa estímulos a la productividad ganadera (PROGAN) en México". Agricultura, Sociedad y Desarrollo 5 (2):213-230.

Linck, T. (1985). "La mecanización de la agricultura de temporal ¿Cuál sociedad elegir?" Comercio Exterior 35 (2): 150-160.

Luna M., N., Jaramillo, J., Ramírez, J., Escobedo, S., Bustamante, Á., \& Campos, G. (2013). "Tipología de unidades de producción de nuez de castilla en sistemas de producción tradicional". Agricultura, Sociedad y Desarrollo 10 (3): 283-303.

Martínez R., A. M., \& Gómez, J. (2012). “Elección de los agricultores en la adopción de tecnologías de manejo de suelos en el sistema de producción de algodón y sus cultivos de rotación den el valle cálido del Alto Magdalena". Revista Corpoica Ciencia y Tecnología Agropecuaria 13 (1):62-70.

Molina, C., \& Álvarez, J. (2009). "Identificación de factores incidentes en las decisiones de adopción de tecnología en productores ganaderos criadores familiares". Agrociencia 13 (2):70-83.

Muñoz L., J. L. (2001). “Herencia piñera reseña histórica de Loma Bonita, Oaxaca". Distribuidora y Editora Mexicana S. A. de C. V. México, D. F. 290 p.

OEIDRUS Oaxaca. (2009). El cultivo de la piña región del Papaloapan. (Publicación en línea, disponible 
en internet en el sitio http://www.oeidrus-oaxaca. gob.mx/publicacionPina/pina2009_archivos/ El\%20cultivo\%20de\%20pina.pdf_[con acceso el 20-09-2015]).

Ortiz J., B., Jiménez, L., Morales, M., Quispe, A., Turrent,..., Rendón, R. (2013). “Nivel de adopción de tecnologías para la producción de jitomate en productores de pequeña escala en el estado de Oaxaca". Revista Mexicana de Ciencias Agrícolas 4 (3):447-460.

Palacios R., M. I., \& Ocampo, J. (2012). “Los tractores agrícolas de México". Revista Mexicana de Ciencias Agrícolas" Pub. Esp. (4): 812-824.

Pérez G., R. O., Martínez, H., López, B., \& Rendón, R. (2016). "Estimación de la adopción de innovaciones en la agricultura". Revista Mexicana de Ciencias Agrícolas (15):2909-2923.

Plan de Municipal de Desarrollo. (2008-2010). H. Ayuntamiento de Loma Bonita, Oaxaca. Loma Bonita, Oaxaca. $113 \mathrm{p}$.

Rebolledo M., A., Uriza, D., del Ángel, A., Rebolledo, L., \& Zetina, R. (2011). "La piña y su cultivo en México. Cayena Lisa y MD2". INIFAP-SAGARPA. Veracruz, México.

Rocha R., C., Mora, J., \& Romero, J. (2016). “Tipología de sistemas de producción en la zona rural del municipio de Ibagué, Colombia". Agronomía Mesoamericana 27 (2):253-254.

Rojas G., C. P. (1998). "Factores físicos y socioeconómicos que explican la no adopción de tecnología moderna por el caficultor en Antioquía y Cundinamarca". Ensayos sobre Economía Cafetera (14):73-100.

SAGARPA-FAO. (2012). Diagnóstico del sector rural y pesquero de México 2012. Secretaría de Agricultura, Ganadería, Desarrollo Rural, Pesca y Alimentación-Organización de las Naciones Unidas para la Alimentación y la Agricultura. 68 p.

SAGARPA-FAO. (2014). Estudio sobre el envejecimiento de la población rural en México. Ciudad de México, México. $67 \mathrm{p}$.

SAGARPA. (2016). La piña, una fruta de excelencia. Secretaría de Agricultura, Ganadería Desarrollo Rural, Pesca y Alimentación. (Publicación en línea, disponible en internet en el sitio https://www. gob.mx/sagarpa/articulos/la-pina-una-fruta-deexcelencia?idiom=es. [con acceso el 20-09-2018]).
Sánchez G., L. G., Solorio, J., \& Santos, J. (2008). "Factores limitativos al desarrollo del sistema familiar de producción de leche en Michoacán, México". Cuadernos de Desarrollo Rural, Bogotá (Colombia) 5 (60):133-146.

Sánchez G., R. A., Zegbe, J., \& Gutiérrez, H. (2015). "Tipificación de un sistema integral de lechería familiar en Zacatecas, México". Revista Mexicana de Ciencias Pecuarias 6 (3):349-359.

Sangermán J., D. M., Larqué, B., Omaña, J., Shwenstesius, R., \& Navarro, A. (2014). "Tipología del productor de aguacate en el Estado de México". Revista Mexicana de Ciencias Agrícolas (6):1081-1095.

SIAP. (2018). Anuario Estadístico de la Producción Agrícola. (Publicación en línea, disponible en internet en el sitio http://nube.siap.gob.mx/ cierre_agricola/[con acceso el 12-06-2018]).

Smith, L. D. (2002). Reforma y descentralización de servicios agrícolas: Un marco de políticas. FAO. (Publicación en línea, disponible en internet en el sitio http://www.fao.org/docrep/005/y2006s/ y2006s00.htm [con acceso el 23-09-2016]).

Solleiro J., L., Del Valle, M., \& Lina, I. (1993). "La innovación tecnológica en la agricultura mexicana". Comercio Exterior abril:353-359.

Traffano, D. (2012). "Historias e imágenes del siglo XX: El Estado de Oaxaca desde sus regiones". Cuadernos del Sur. Revista de Ciencias Sociales 17 (32):9-28.

Vargas C., J. M., Palacios, M., Camacho, J., Aguilar, J., \& Ocampo, J. (2015). “Factores de innovación en la agricultura protegida en la región de Tulancingo, México". Revista Mexicana de Ciencias Agrícolas 6 (4):827-840.

Vargas L., B., Solís, O., Sáenz, F., \& León, H. (2013). "Caracterización y clasificación de hatos lecheros en Costa Rica mediante análisis multivariado". Agronomía Mesoamericana 24 (2):257-275.

Velasco F., J., Ortega, L., Sánchez, E., \& Urdaneta, F. (2009). Factores que influyen sobre el nivel de adopción tecnológico presente en las fincas ganaderas de doble propósito localizadas en el estado de Zulia, Venezuela. Revista Científica 19 (2):187-195.

Vélez I., A., Espinosa, J., Omaña, J., González, T., \& Quiroz, J. (2013). "Adopción de tecnología en 
unidades de producción lechería familiar en Guanajuato, México". Actas Iberoamericanas de Conservación Animal (3):88-96.

Vicini L., E. (2000). "Adopción de tecnología agrícola". Horizonte Agroalimentario Julio:10-13.

Vilaboa A., J., Díaz, P., Ruiz, O., Platas, D., González, S., \& Juárez, F. (2009). “Caracterización socioeconómica

y tecnológica de los agroecosistemas con bovinos de doble propósito de la Región del Papaloapan, Veracruz, México". Tropical and Subtropical Agroecosystems 10 (1):53-62.

Walter T., J. (2007). “Determinantes de la producción orgánica: el caso del café orgánico en los valles de San Juan del Oro - Puno". Economía y Sociedad (64):74-79. 
